\title{
دلالة لفظ ( الكتاب ) في الاستعمال القرآني
}
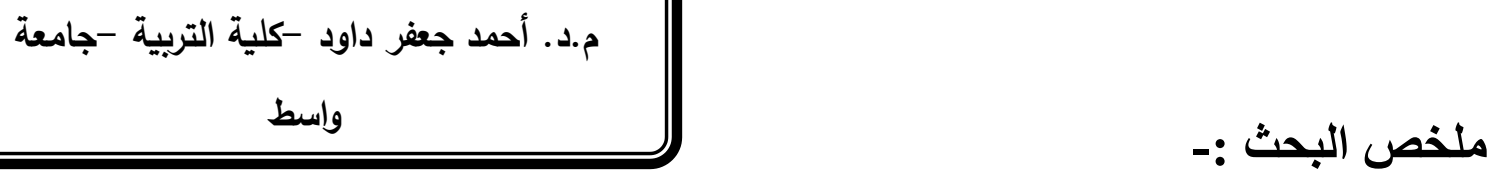

لفظ (الكتاب ) من الألفاظ التي أوردت لها المعجمات اللغوية معاني متنوعة ، وهذا البحث

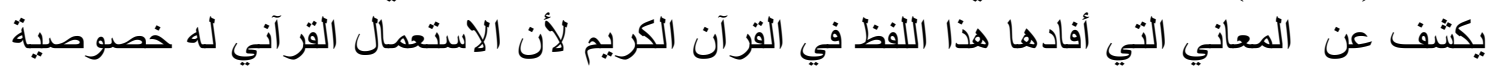

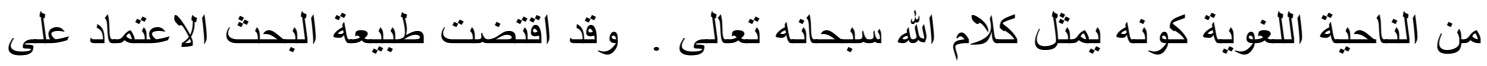

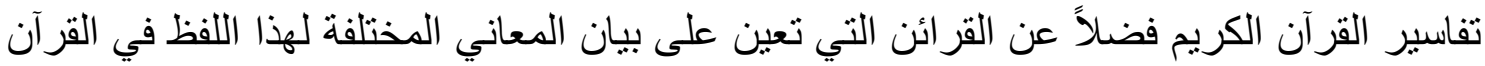

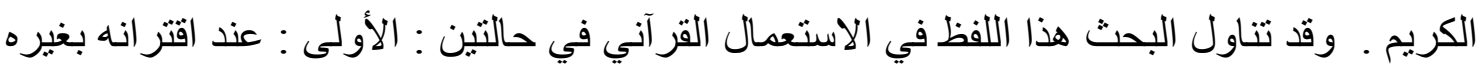

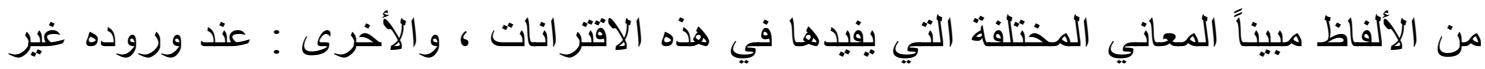

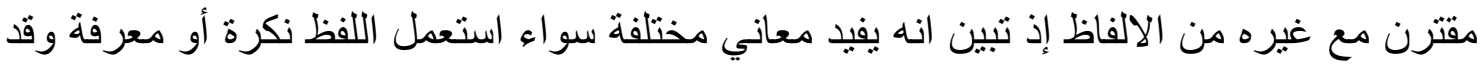
أحصى البحث ثمانية معاني مختلفة لهذا اللفظ عند استعماله غير مقترن مع غيره من الألفاظ في دئ دئ

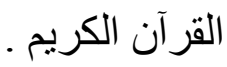

\section{Abstract}

This research deals with the connotation of the term (Alkitab)in the holly Qur'an The term (Alkitab) is one of the mutual articulation terms that it refers to more than one meaning, hence, the language dictionaries offer various numbers of meaning for this term .

This research is devoted for exploring the different meanings of this term in the holly Qur'an that the holly Qur'an's use of the terms is unique since it is the utterance of the Allah almighty.

The nature of this research required to depends on the books of holly Qur'an explanation in addition to the related theories which help in the determining and interpreting of the different meanings of this term in the holly Qur'an.

This research found out that this term combined with the another different terms, thus, this association results in many different meanings, 
while when it comes alone ( without combination) presents another different meanings whether it is used as a definite or indefinite term ,meanwhile, this research accounted eight different meanings for this term when it isn't combined with the another terms of the holly Qur'an terms .

$$
\text { دلالة لفظ ( الكتاب ) في الاستعمال القر آني }
$$

عند الرجوع إلى المعجمات اللغوية نجد أن الجذر ( كتب ) يدل على ( جمع شيء إلى شيء )(1)،

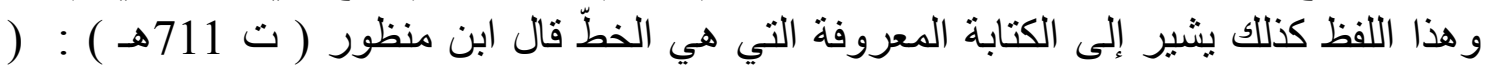

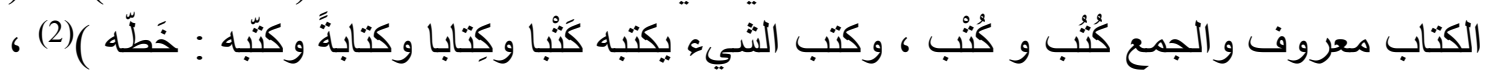

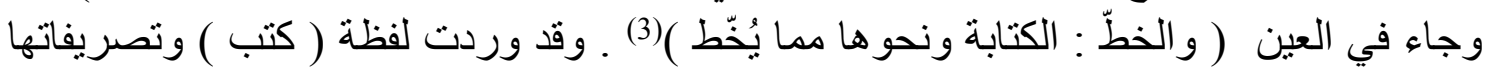

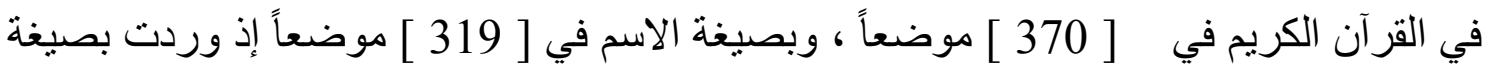

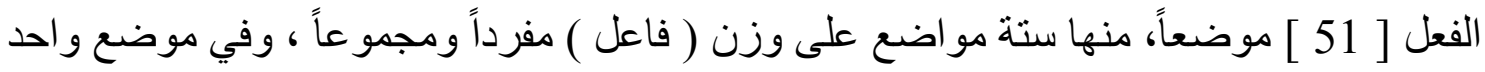

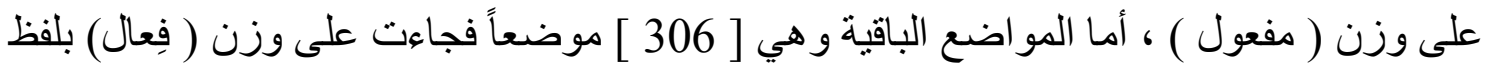
( كتاب ) مفرداً ومجموعاً ، وقد وهم الدكتور حسام سعيد النعيمي عندما ذهب الى الى أن (كتب)

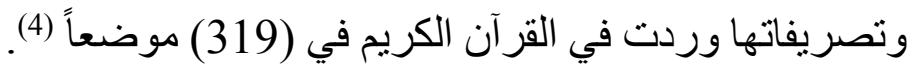

و عند النظر في الاستعمال القرآني للفظ ( كتب ) وما صيغ منه من الأفعال نجد أنه أستعمل

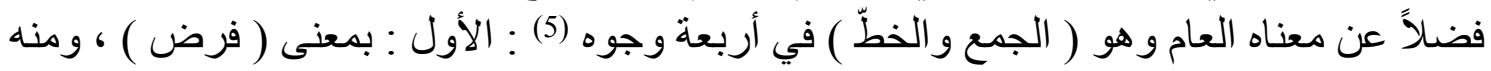

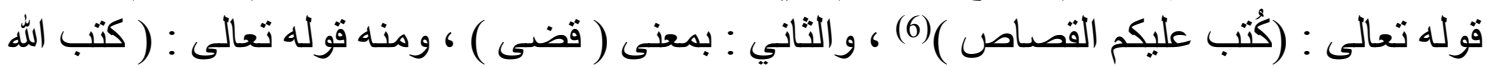

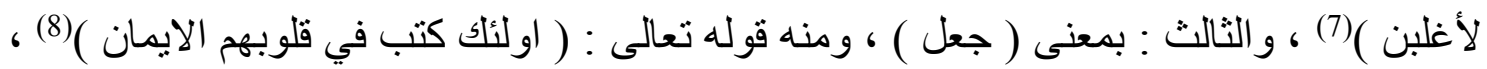
و الر ابع : بمعنى(أمر ) ومنه قوله تعالى : ( يا قوم أدخلوا الأرض المقدسة التي كتب الله لكم )(9 ) : و البحث يحاول الوقوف على دلالة لفظ ( الكتاب ) في القرآن الكريم ، ولكي نقف على المعاني التي

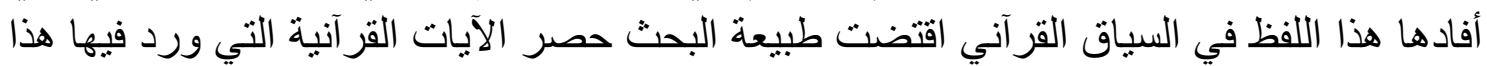
اللفظ للنظر في طبيعة العلاقة التي تربطه بغيره من الألفاظ ، ليتسنى لنا الوقوف على التى المعاني التي

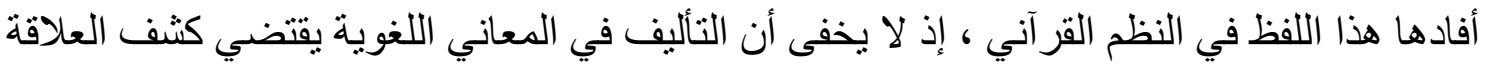

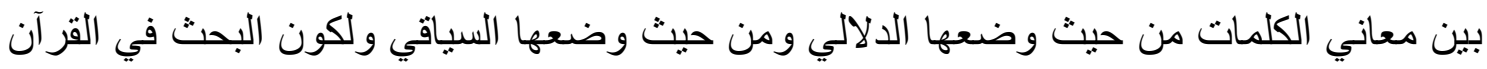

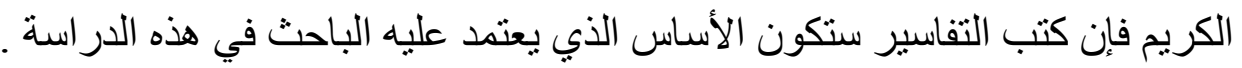




\section{لفظ ( الكتاب ) عند اللغويين :}

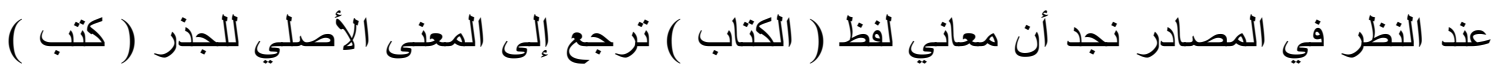

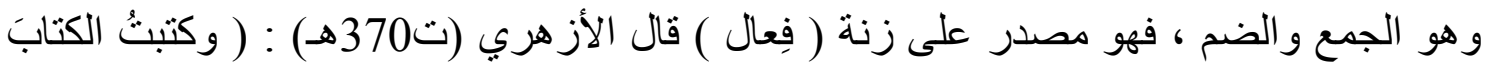

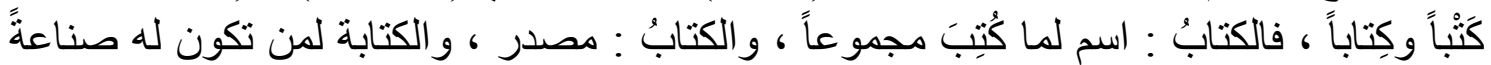

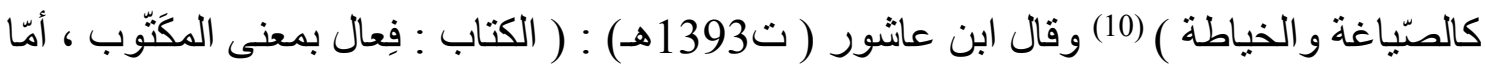

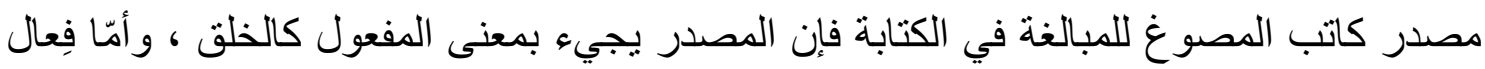

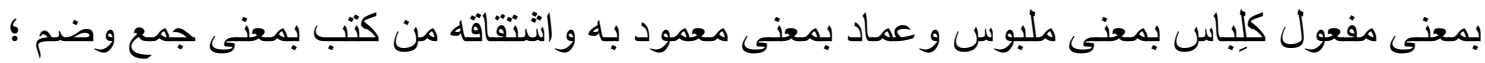

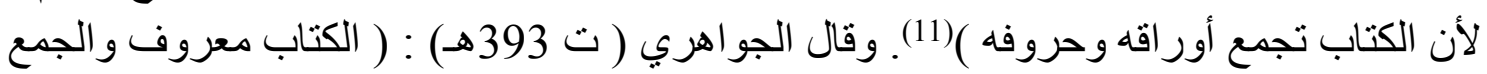

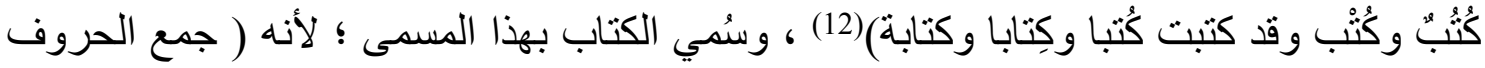

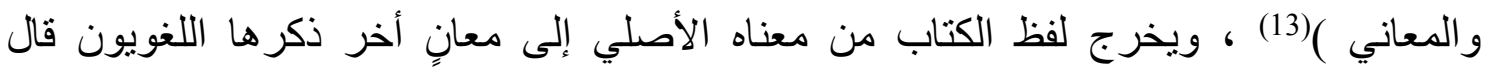

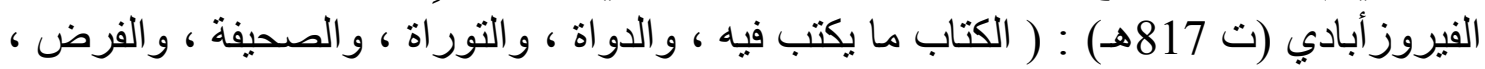

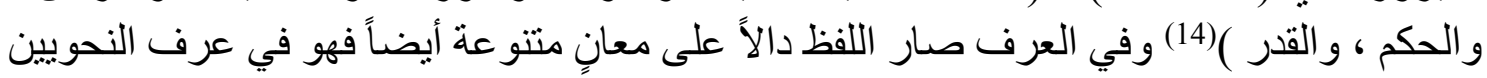

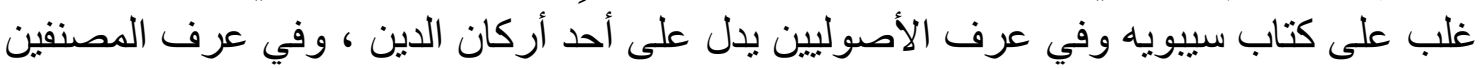

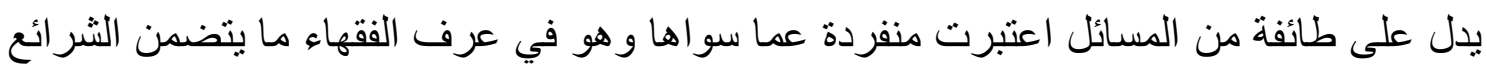
والأحكام (15)

ويظهر من تنوع المعاني للفظ الكتاب أنه من الفاظ المشترك اللفظي وهو ما سماه الأقدمون ( ما

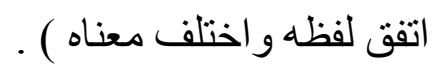

\section{الكتاب في الاستعمال القرآني :}

سبق وذكرنا أن صيغة ( كتب ) بتصريفاتها الاسمية وردت في [ 319 ف 319 ـ موضعاً ، و عند النظر في

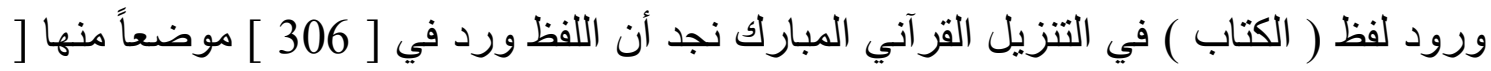

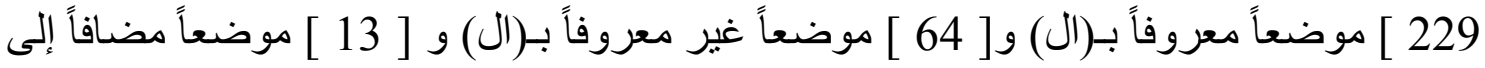

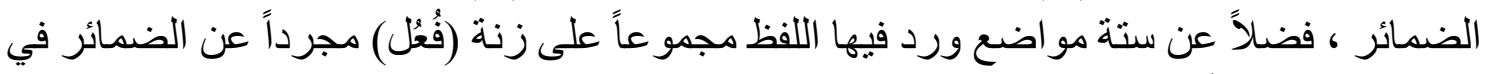
ثلاثة منها ومضافاً إلى ضمير الغائب ( الهاء ) في ثلاثة مو اضع أخع أخرى .

اقترانات لفظ ( الكتاب ) بغيره من الألفاظ في الاستعمال القرآني : 
اقترن لفظ ( الكتاب ) في الاستعمال القرآني بطائفة من الألفاظ ، وقد تنوع الموقع الإعرابي له في

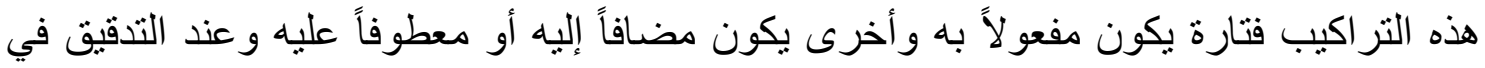

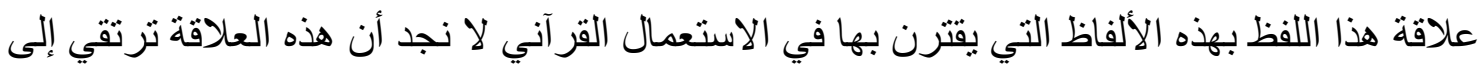
ما يسميه اللغويون المحدثون بالرصف وهو :(استعمال وحدتين معجميتين منفصلتين استعمالهما عادة مرتبطنتين الواحدة بالأخرى)(16) ؛ لأن هذا اللفظ استعمل منفرداً غير مقترن بلفظ آخر أكثر

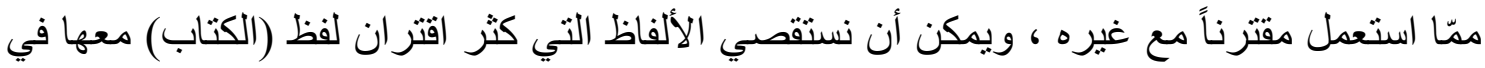

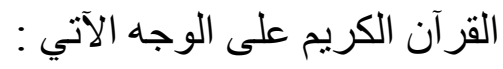

اقترن لفظ ( الكتاب ) معرفاً مضافاً إليه في التركيب مع لفظ (أهل ) في [ 31 م 31 موضعاً ،

\section{1}

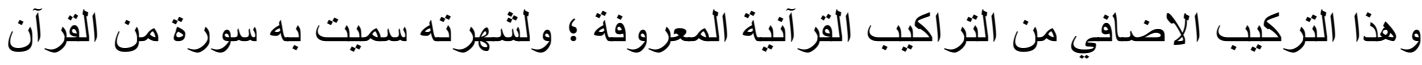

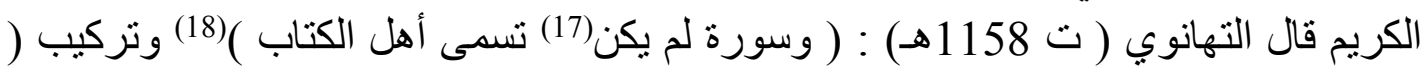

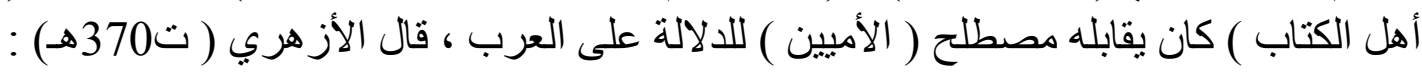

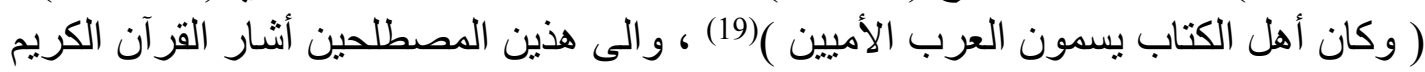

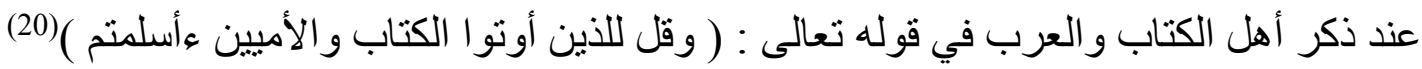
، ويذهب كثير من القدامى والمحدثين إلى حصر دلالة ( أهل الكتاب ) باليهود و النصارى قال فال

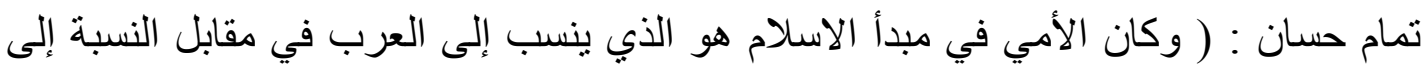

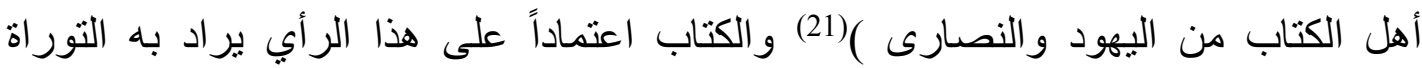

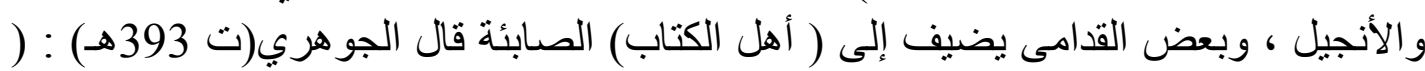

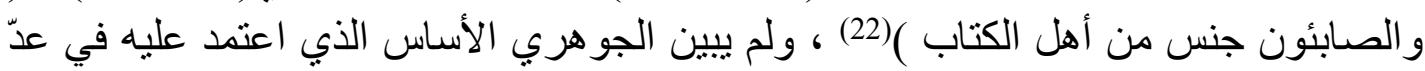

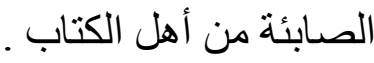

و عند التدقيق في ورود تركيب ( أهل الكتاب ) في القرآن الكريم نجد أنه ورد في سورة آل في آل

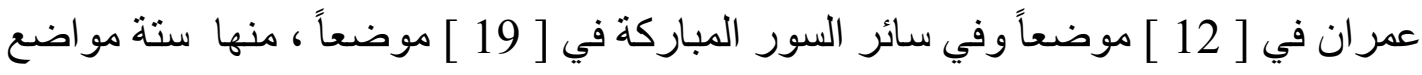

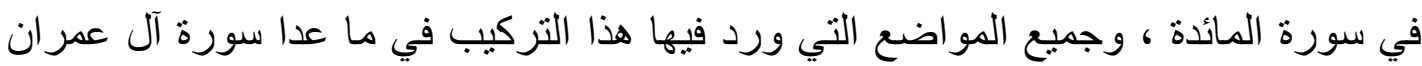

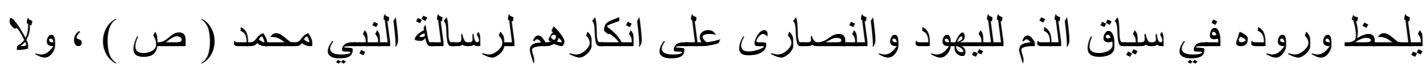

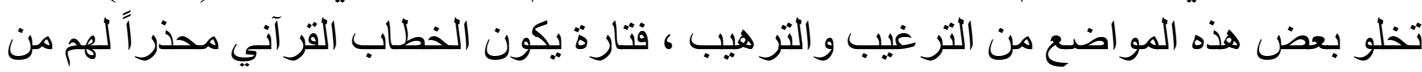

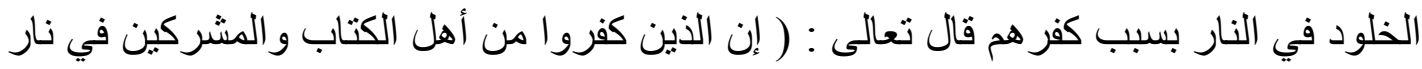

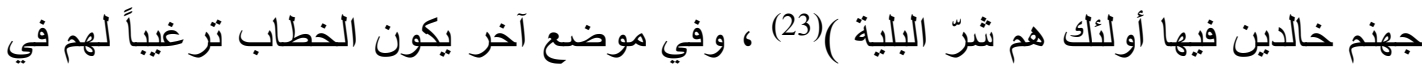
حال ايمانهم وتقواهم قال تعالى : ( ولو أن أهل الكتاب آمنوا واتقوا لكفرّنا عنهم سيئاتهر

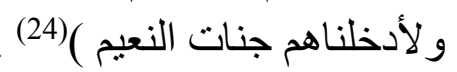
ولقد وجدت لهذا التركيب خصوصية في سورة آل عمران فضضلاً عن كثرة المواضع التي ورد فيها نستطيع أن نحدد ملامح اتجاهين للخطاب القر آني في استعماله و هما : 
الاول : محاولة التقريب بين النبي محمد (صلى الله عليه وآله وسلم) و أصحابه من جهة وبين

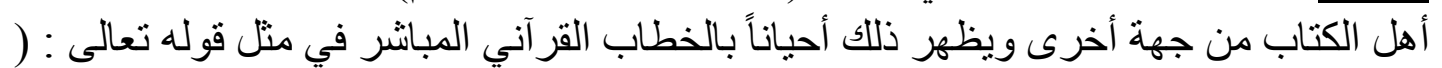

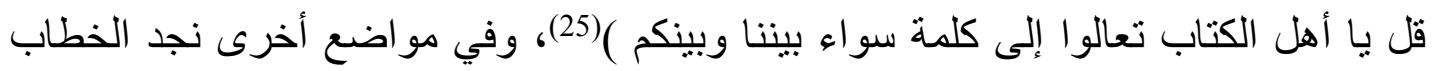
القر آني يميل إلى استعمال أسلوب النداء متبو عاً بالاستفهام الانكاري بصيغة البعة (ما) الاستفهامية

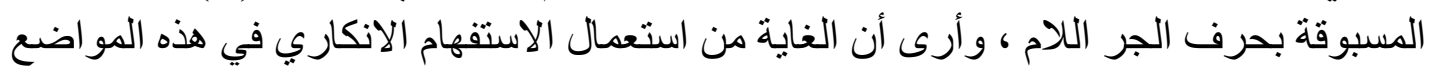

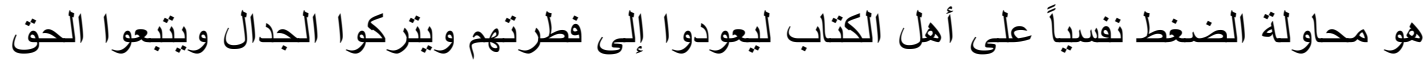

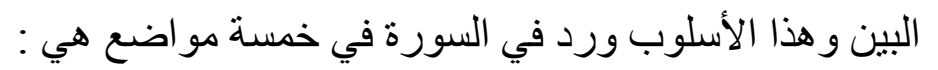

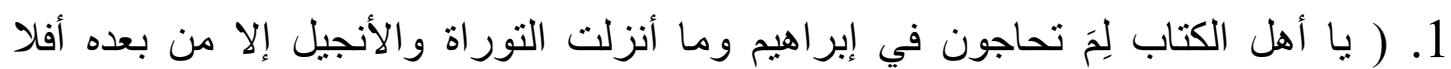

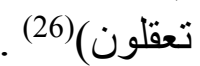

2. ( يا أهل الكتاب لِحَ تكفرون بآيات الله و أنتم تشهدون )(27) .

3. ( يا أهل الكتاب لِحَ تلبسون الحق بالباطل وتكتمون الحق و أنتم تعلمون )(28).

4. ( قل يا أهل الكتاب لِحََ تكفرون بآيات الله والله شهيد على ما تعملون )(29) .

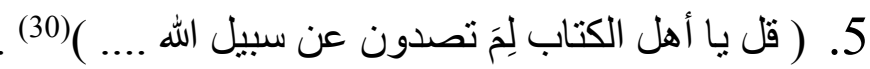

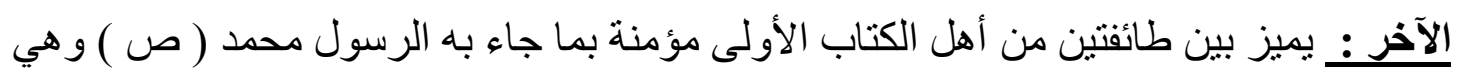

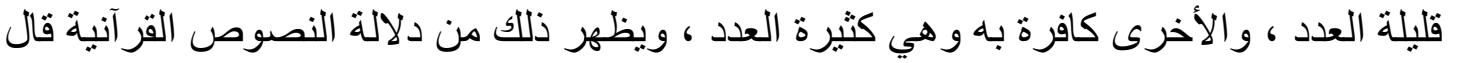

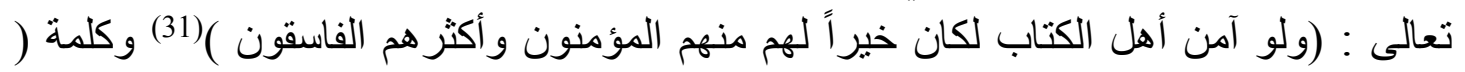

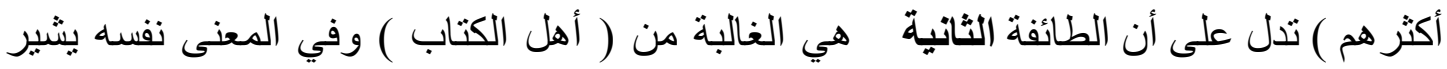
تعالى في موضع آخر من سورة البقرة :( ودّ كثير من أهل الكتاب لو يردونكم من بعد الهد إيمانكم

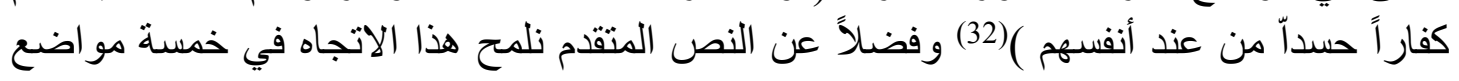

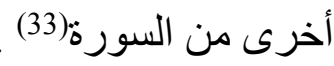

\section{: 2}

من التر اكيب القرآنية وهو تركيب إضافي ورد مسبوقاً باسم الاشارة ( تلك )في جميع المواضع

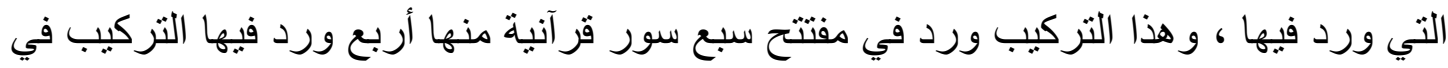

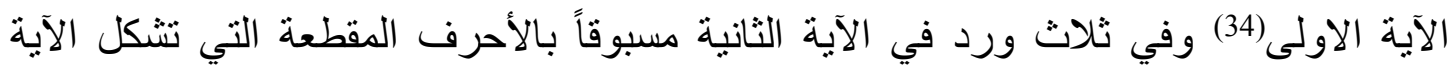

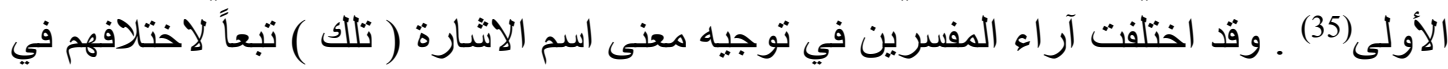

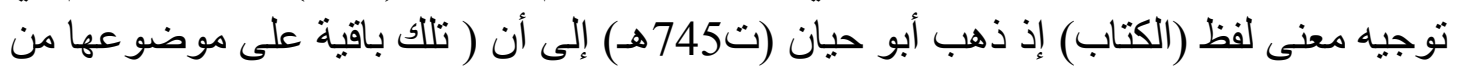

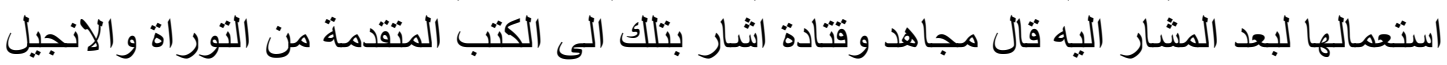
و الزبور فيكون الآيات القصص التي وضعت في تلك الكتب )(36) ، و وعلى هذا الرأي فإن اسم

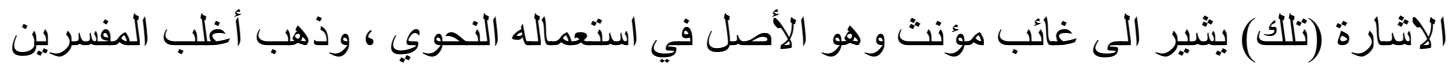

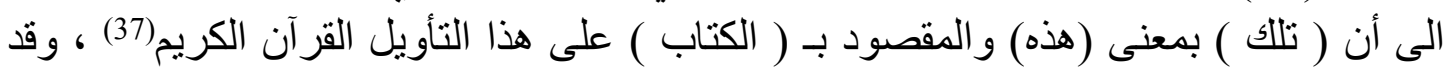


أورد القرطبي (ت671هـ) الر أيين وهو يميل الى الثاني منها معلاً إذ قال : ( قال مجاهد وقتادة :

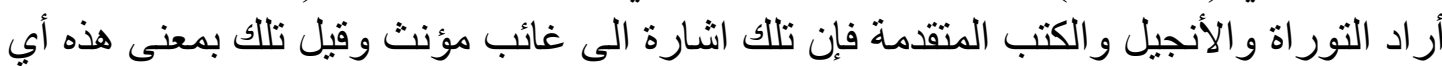

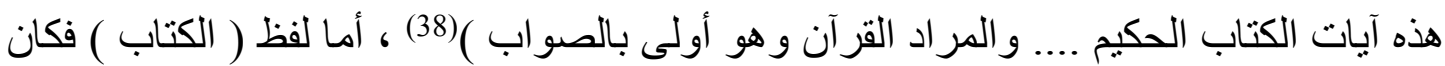
الاختلاف فيه كبيراً بين المفسرين في تركيب (آيات الكتاب) ويمكن حصر المعاني التي أوردها المفسرون على النحو الآتي : - الآنيل

أ. بمعنى القرآن : ذهب كثير من المفسرين(39) الى أن معنى الكتاب في تركيب ( تلك آيات

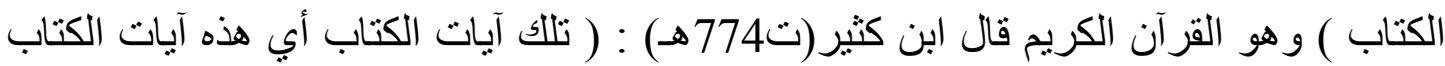

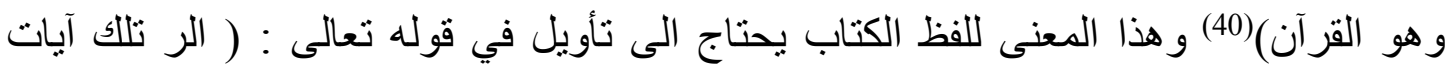
الكتاب وقرآن مبين )(41) ، إذ جمع تبارك وتعالى بين لفظ ( الكتاب ) وتركيب ( قرآن مبين ) بحرف العطف الواو والعطف يقتضي المغايرة ، وقد أثار السمعاني(ت489هـ) هذا التساؤل

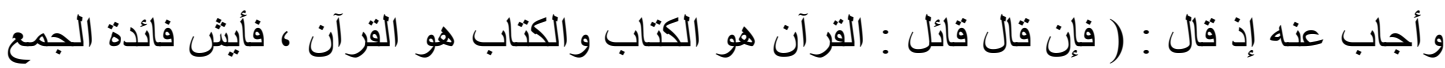

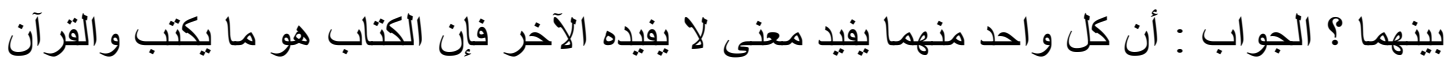

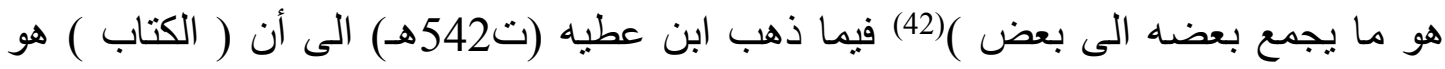

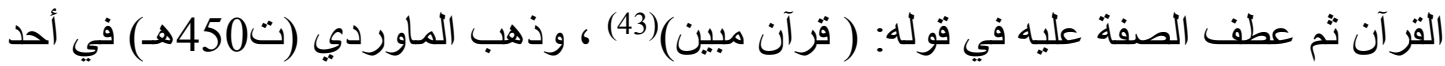
قوليه الى أن ( الكتاب هو القرآن جمع له بين الاسمين )(44) وتابعه على هذا الرأي الثوكاني

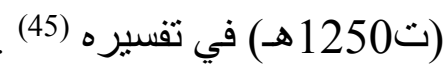

ب. بمعنى التوراة والاتجيل : ذكر ذللك طائفة من المفسرين ناسبين الر أي الى مجاهد وقتادة(46)

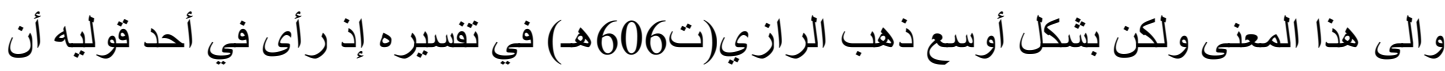

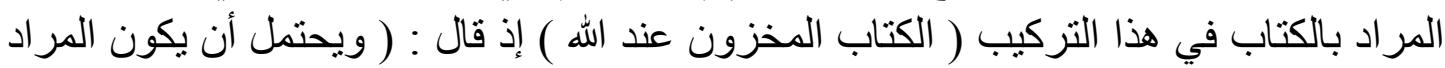
منه غير القرآن و هو الكتاب المخزون المكنون عند الله تعالى الذي منه نسخ كل كتاب )(47) . ت. بمعنى السورة : وذهب الى هذا الر أي الزمخشري ( ت538هـ) عند تفسيره لهذا التركيب إذ إذ إناب

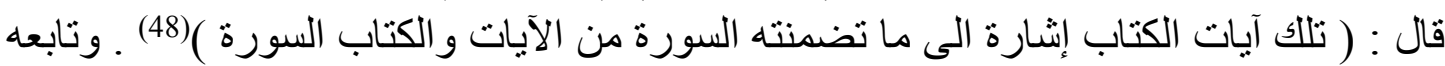
في هذا الرأي طائفة من المفسرين منهم النسفي (ت ذهب الى هذا الر أي في مواضع(50) وذهب اليه والى غيره غير مرجح في موضع آخر إذ فال عند تفسير الآية الأولى من سورة يونس : ( تللك آيات الكتاب الحكيم اشتارة الى ماتى ما تضمنته

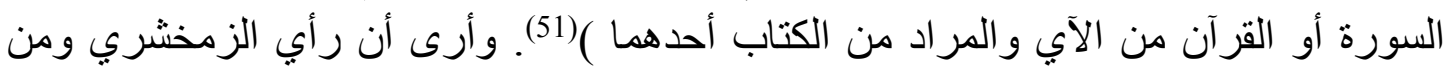

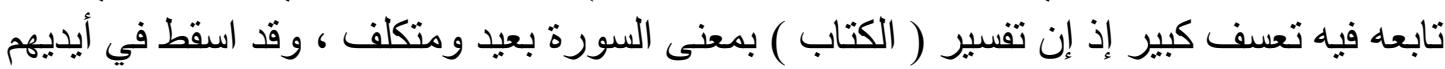

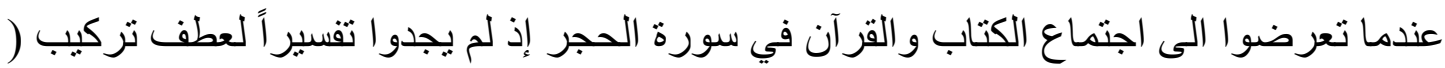
قر آن مبين ) على تركيب ( تللك أيات الكتاب ) وما الفائدة إذا كان اللفظان بمعنى واحد قال الزمخشري: ( تللك اشتارة الى ما تضمنته السورة من الآيات والكتاب و القرآن المبين : السورة 


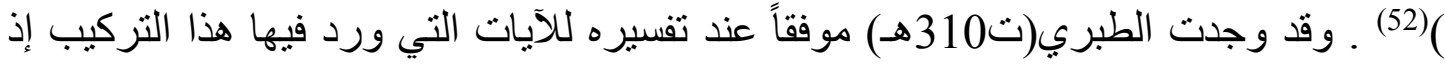

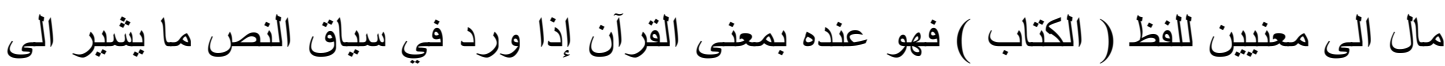

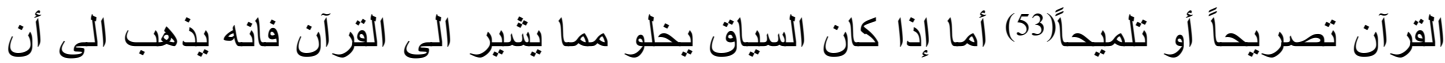
معنى الكتاب هو التور اة والانجيل .

3. تنزيل الكتاب :

من التر اكيب القر آنية وقد ورد في خمسة مو اضع في القرآن الكريم(54) ولفظ ( تنزيل ) مضافاً الى لفظ ( الكتاب ) أو غير مضاف ورد في التنزيل المبارك في عشرة مواضع فئ ، وفي وفي جميع

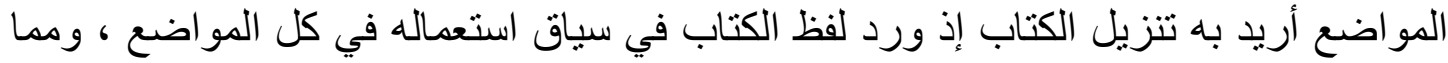
يلفت النظر في استعماله أن كل الآيات المباركة التي ورد فيها جاءت بعده الفاظ تشير الى صفات التهات

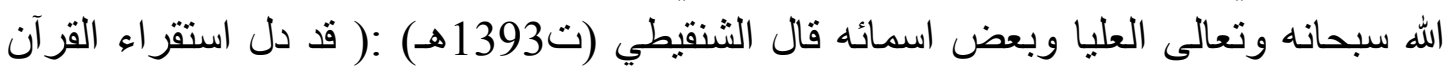

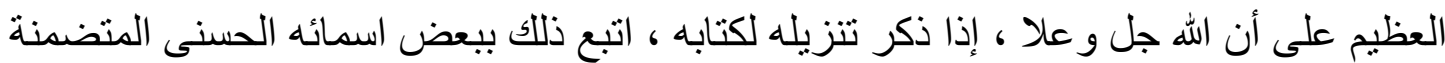

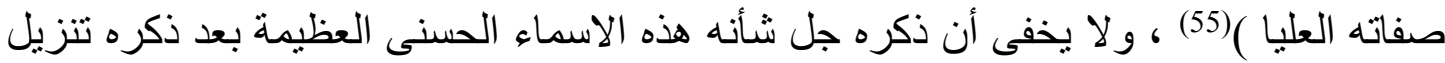

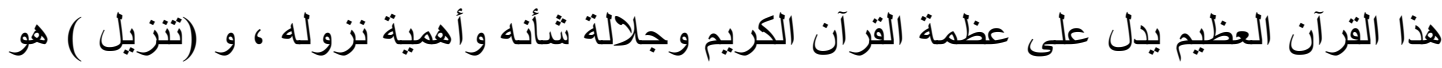

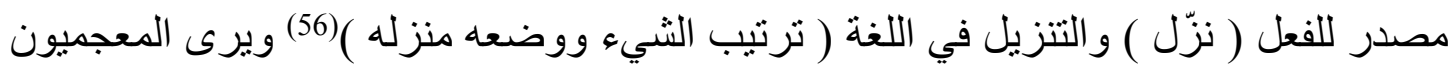

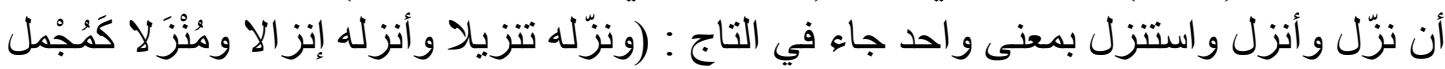

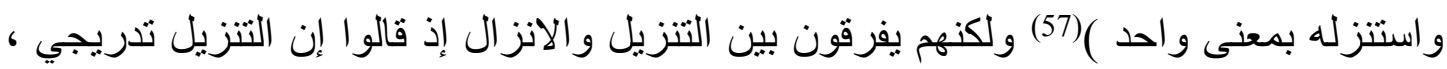

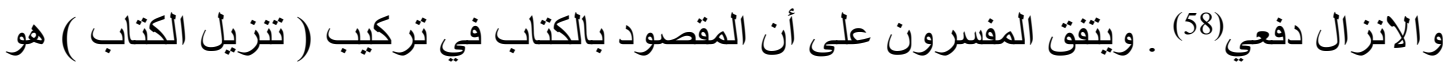

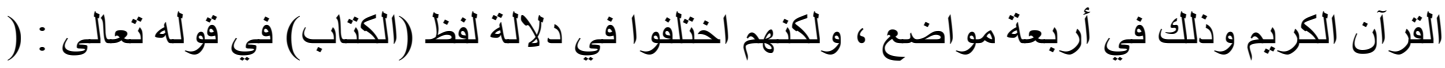

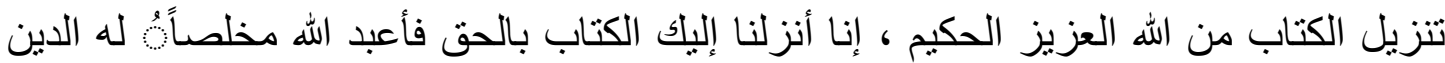
)(59) وذللك لتكرر لفظ الكتاب إذ ذهب أبو حيان (ت

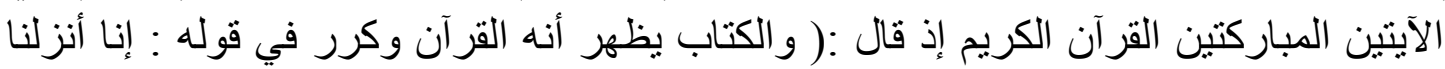

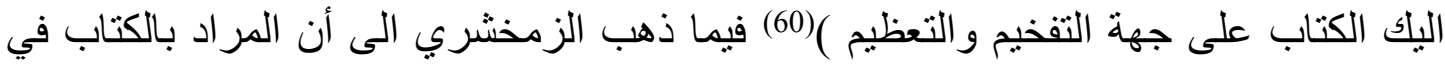

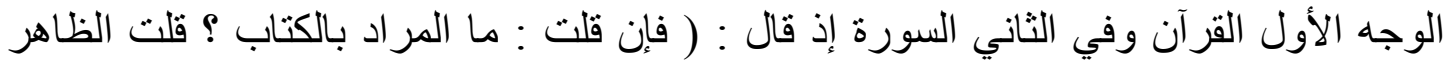

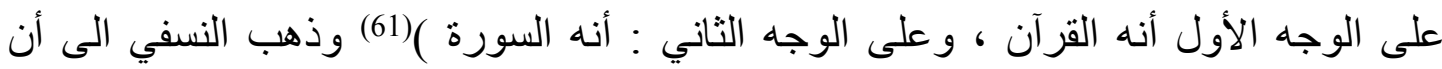
المقصود بـ(الكتاب ) في تركيب ( تنزيل الكتاب ) القرآن الكريم وأن لفظ ( الكتاب ) في في فوله الهابه تعالى: ( إنا أنزلنا إليك الكتاب ) ليس بتكر ار لما قبله : ( لأن الأول كالعنوان للكتاب و الثاني لبيان

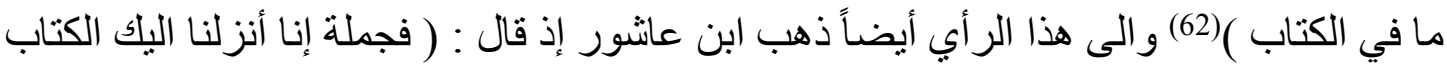

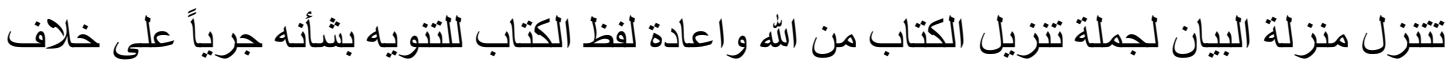
مقتى الظاهر بالاظهار في مقام الاضمار )(63) . 
وخالف ابن عطية المفسرين في تفسير لفظ الكتاب في هذا التركيب في هاتين الآيتين إذ قال : (قال المفسرون : هو القرآن ، ويظهر إلي أنه اسم علم لجميع ما تنزل من عند الله من الكتب . و الكتاب الثاني هو القرآن لا يحتمل غير ذلك الك )(64).

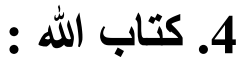

و هو من التر اكيب القرآنية وفيه يتركب لفظ ( الكتاب ) نكرة مضافاً الى لفظ الجلالة ( الله ) في

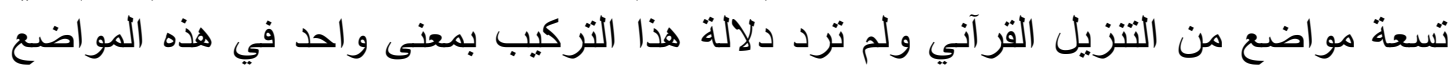
ونستطيع أن نحدد المعاني التي أفادها هذا التركيب عن على دلى النحو الآتي :

أ. القرآن الكريم : أفاد هذا التركيب معنى القرآن الكريم بصورة و اضحة وجلية في قوله تعالى :

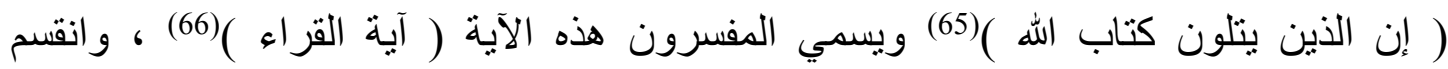
المفسرون في تحديد دلالة هذا التركيب في قوله تعالى : ( و الذين آمنوا من بعدُ وهاجروا

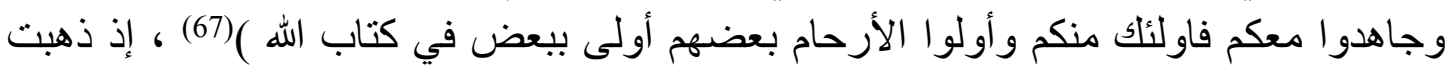

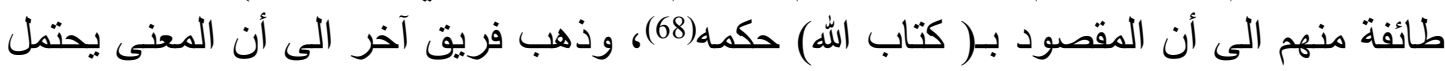

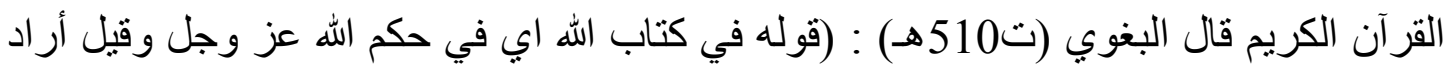
بكتاب الله القرآن )(69) وفي قوله تعالى : ( ولما جاءهم رسول من عند الله مصدق لما معهم نبذ

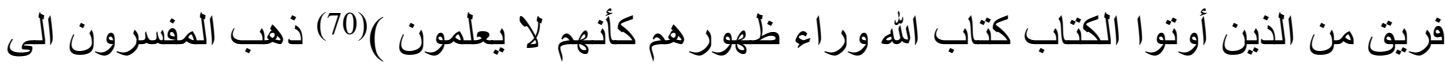
أن المر اد بتركيب (كتاب الله) هو التور اة(71) ولكن ابن عطية ذهب الى أن النقاء المقصود في الآية هو

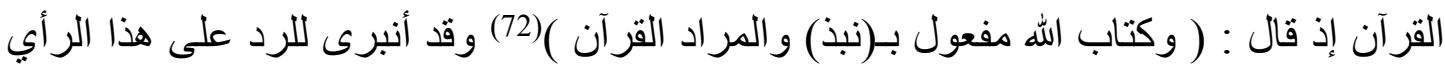

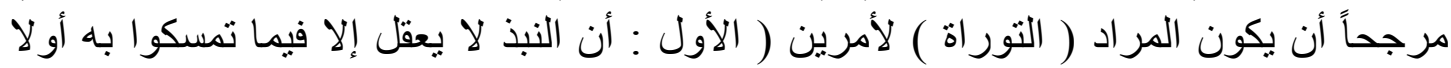

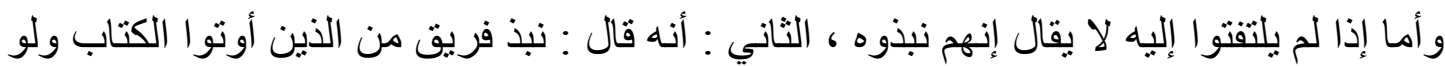
كان المر اد به القر آن لم يكن لتخصيص الفريق معنى لأن جميعهم لا يصدقون بالقر آن)(73) .

ب. التوراة : أريد بتركيب (كتاب الله) التوراة في ثناثة مو اضع من التنزيل وقد ورد في سياق

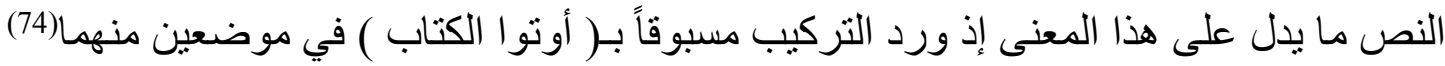
مما يقوي دلالتهما على معنى (التور اة ) في الموضعين وفي الموضع الثالث سبق التركيب بلفظ التور اة وذلك في قوله تعالى : (إنا انزلنا التور اة فيها هدى ونور يحكم بها فيا النبيون الذين اسلموا

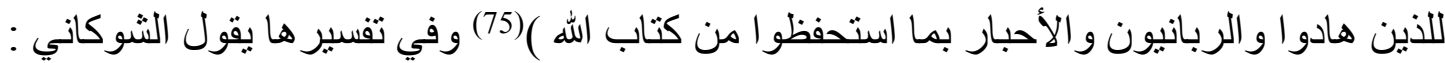

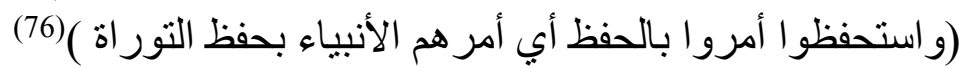

ت. حكم الله : من المعاني التي أفادها تركيب (كتاب الله) في الاستعمال القرآي في أربعة مو اضع(77) وفي جميعها هو مسبوق بحرف الجر ( في ) الذي يفيد الظرفية التي قد تكون حقيقية

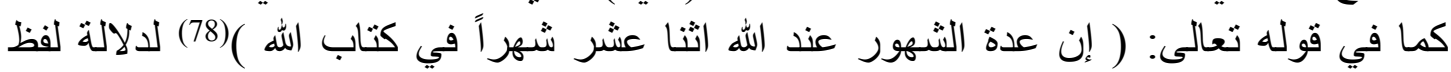


(شهر) على الزمان فتكون الظرفية زمانية وفي قوله تعالى : ( وقال الذين أوتو العلم و الايمان

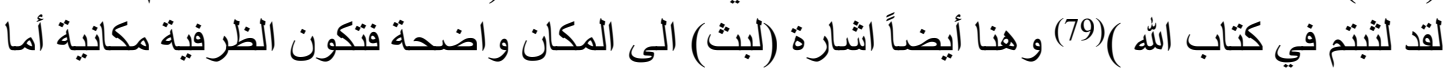

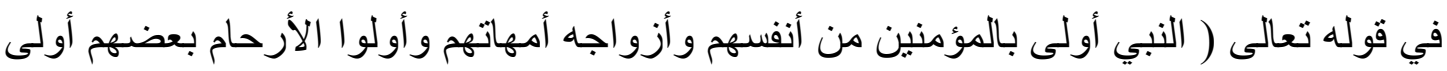

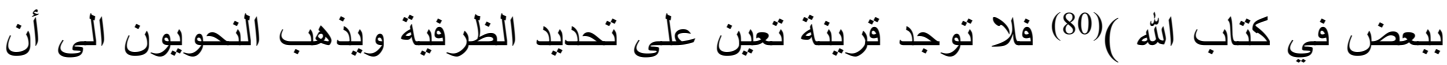

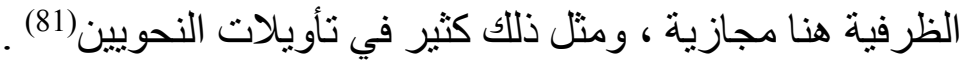

من التر اكيب القرآنية المعروفة ، و هو تركيب اسنادي ولفظ ( أُوتوا ) بالبناء للمفعول ورد في

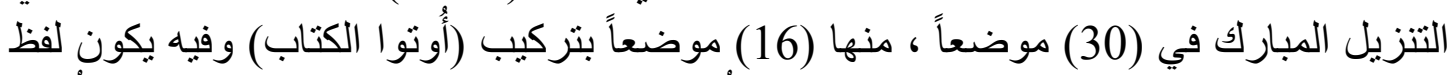

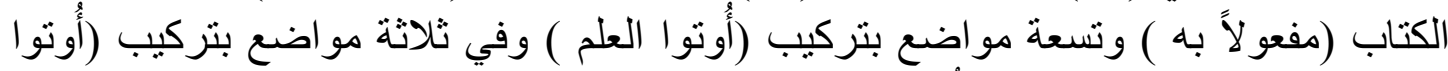

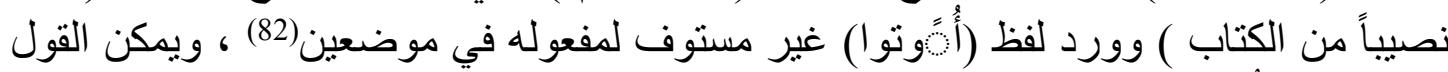

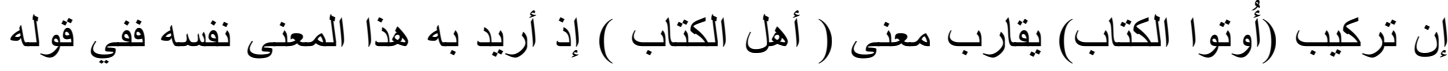
تعالى : ( فإن حاجوك فقل أسلمت وجهي لله ومن اتبعن وقل للذين أوتو الكتاب الكتاب و الأميين ءأسلمتم فإن اسلموا فقد اهتدوا وإن تولوا فإنما عليك البلاغ )(83) يذهب المفسرون الى أن (أوتوا الكتاب)

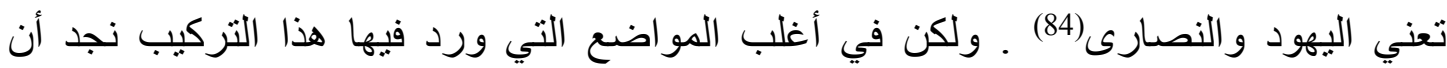

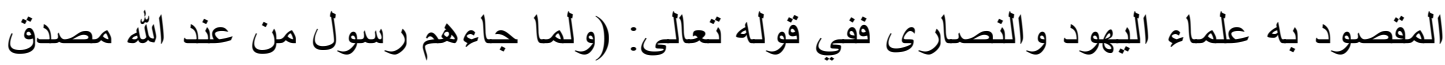
لما معهم نبذ فريق من الذين أوتوا الكتاب كتاب الله وراء ظهور هم كأنهم لا يعلمون) (85) ذهب (له

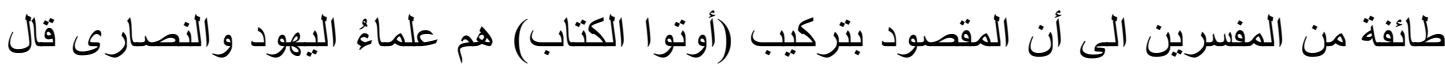

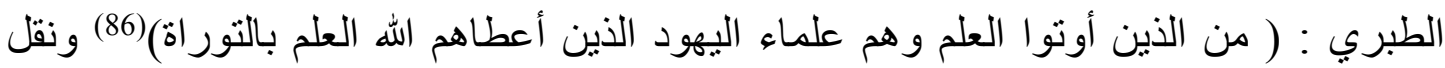

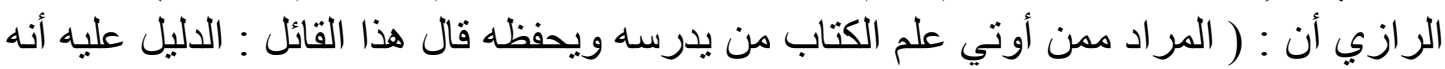

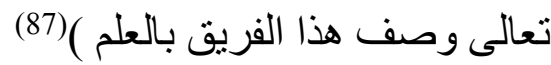

ويثرجح عندي أن الاستعمال القرآني لتركيب (أونوا الكتاب ) ير اد به علماء اليهود و النصارى

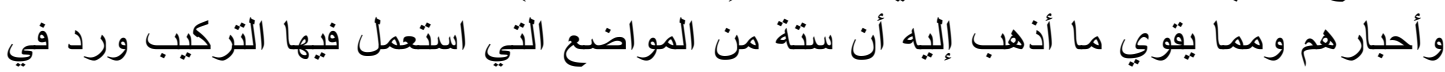

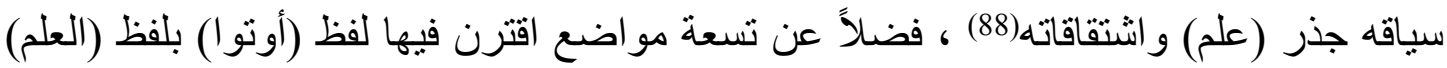
في تركيب (أوتوا العلم)(89) ، أمّا التركيب الثالث (أوتوا نصيباً من الكتاب ) فقد واع ورد مسبوقاً بالاستفهام و النفي بتركيب (ألم تر) في المواضع الثلاثة التي ورد فيها(90) وهو قريب في معناه

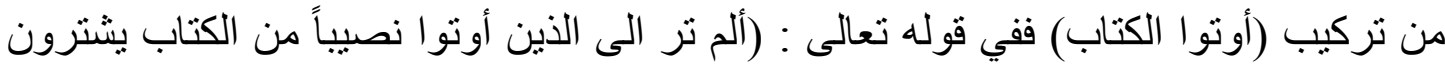

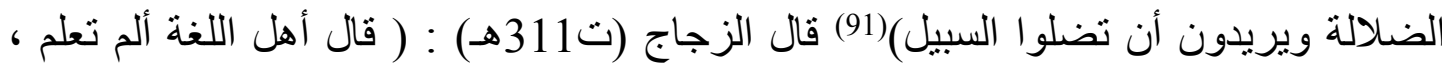

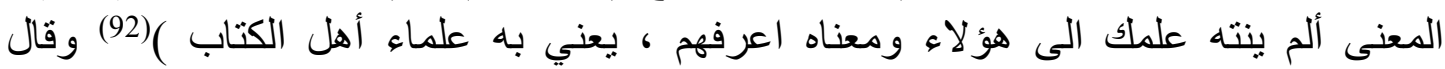

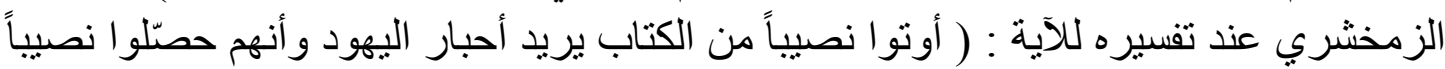

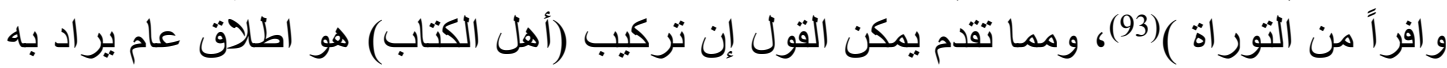


اليهود و النصارى وتركيب (أونوا الكتاب) هو اطلاق خاص ير اد به علماؤهم وأحبار هم وأن

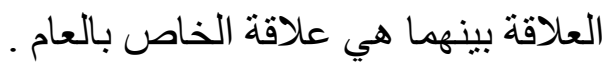

وقد وجدت أن أبا حيان قد اضطرب في تفسيره عند تعرضه لتركيب (أوتوا الكتاب) فتارة نجده

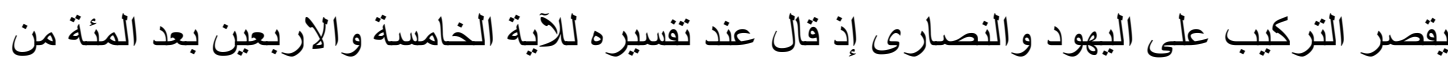

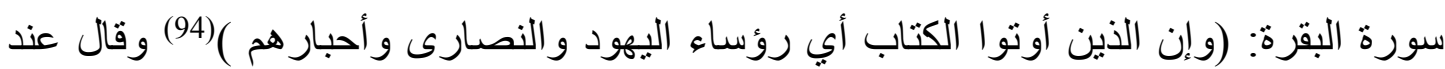

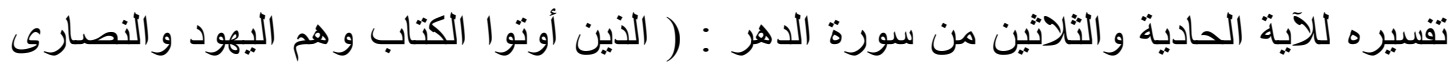

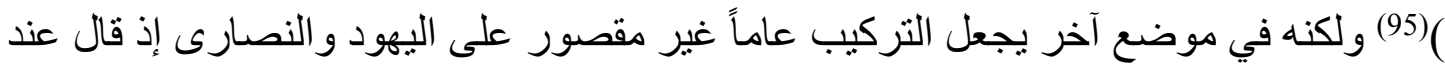

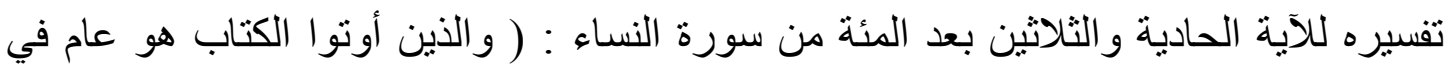
الكتب الالهية ولا ضرورة تدعو الى تخصيص الذين أوتوا الكتاب باليهود و النصارى كما ذهب بعض المفسرين) (96)

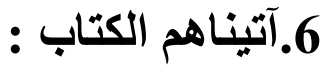

تركيب ورد في القرآن الكريم في ثمانية مواضع ، وهو مركب اسنادي والفعل (آتى) مصدره

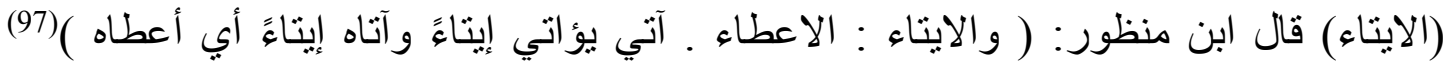
و المقصود بالتركيب (الذين أعطيناهم الكتاب ) بحسب الأبن المعنى المعجمي .

وقد اختلفت دلالة لفظ (الكتاب ) في هذا التركيب في الاستعمال القرآني ويمكن أن نحدد المعاني التي أفادتها على النحو الآتي :

أ. التوراة والانجيل : إذ أُريد بلفظ الكتاب التور اة والانجيل وأن تركيب (آتيناهم الكتاب) دل على فئتين من أهل الكتاب : الأولى : وتشمل اليهود و النصارى وذلك في ثنلاثة مو اضع وقد يقيد بعض المفسرين الدلالة فيذهب الى أنه يعني العلماء منهم ، وفي جميع المواضع اضع ورد التركيب

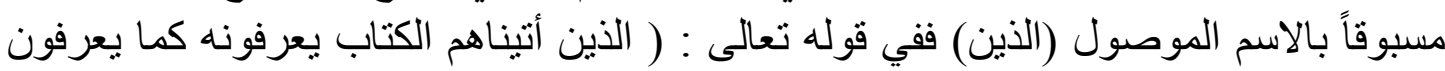

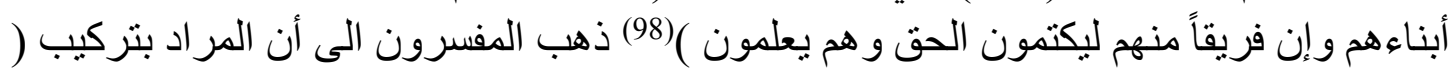

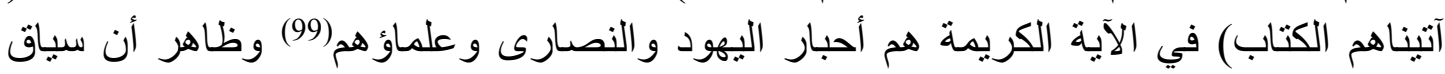
النص يدل على صحة ما ذهب اليه المفسرون في تقييد الدلالة بعلماء أهل الكتاب ، أمّا في قوله الهاريه

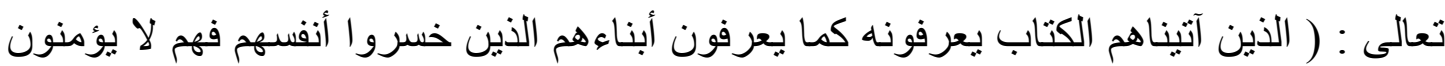
(100) وقوله تعالى : ( أفغير الله أبتغي حكماً وهو الذي أنزل اليكم الكتاب مفصلاً و الذين آتيناهم

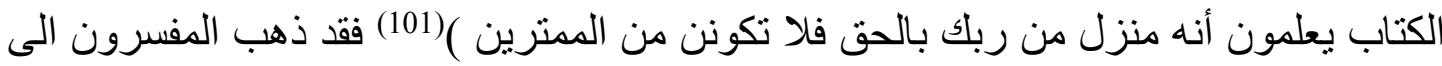

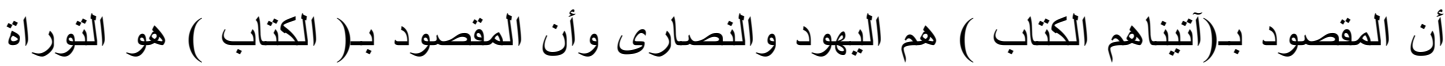


و الانجيل(102) ، و الأخرى : وير اد بها مؤمنو أهل الكتاب و هم من آمن بالنبي محمد (ص) وصدق آله

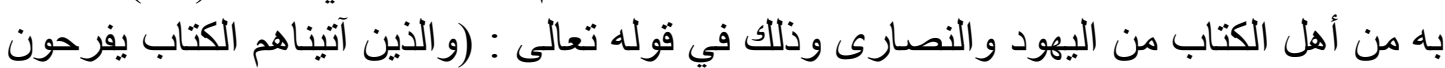

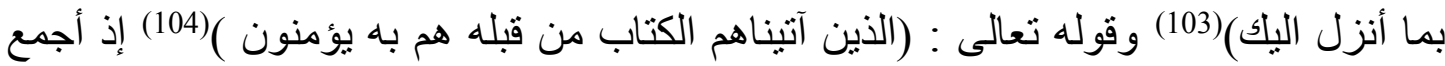

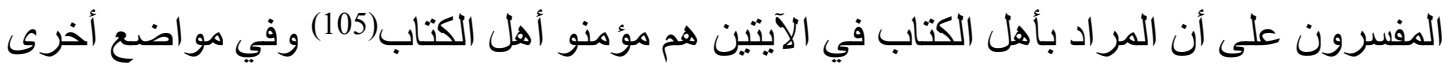

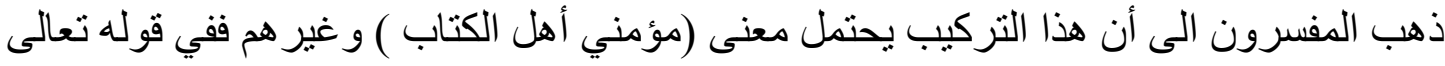

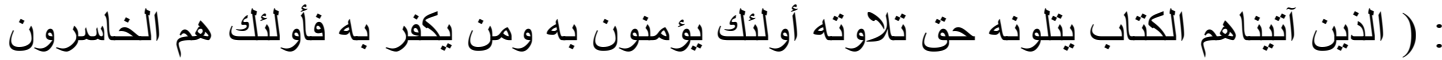

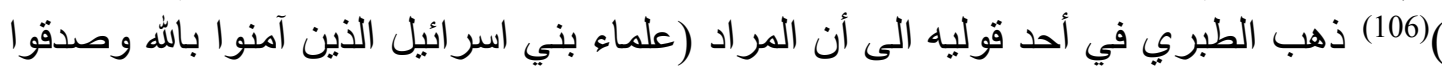

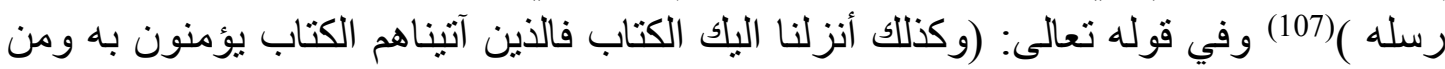
هؤلاء من يؤمن به وما يجحد بآياتنا إلا الكافرون)(108) ذهب المفسرون الى أنى أن هذا التركيب

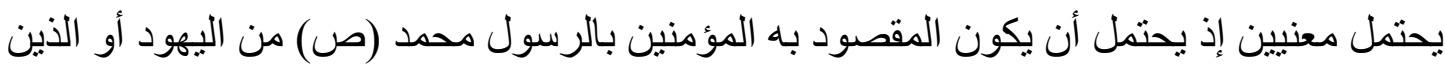

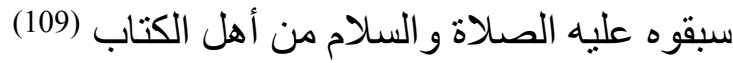

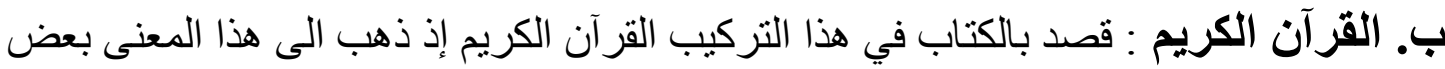

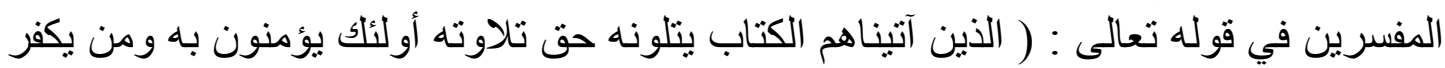
به فأولئك هم الخاسرون )(110) إذ ذهب الطبري في في أحد قوليه الى المقصود بـ بالكتاب في هذا

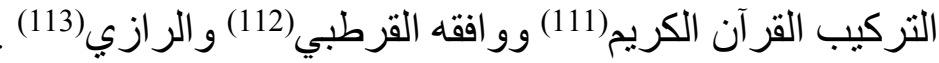

ث. الكتب السماوية : إذ ذهب المفسرون الى أن المقصود بلفظ الكتاب في تركيب (آتيناهم الكتاب ) في قوله تعالى : ( أولئك الذين آتيناهم الكتاب والحكم و النبوة فإن يكفر بها هؤلاء فقد

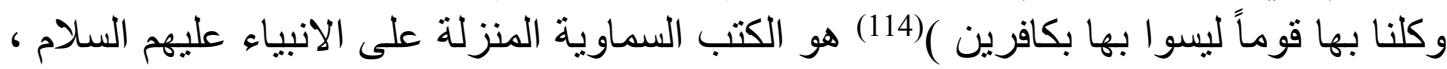

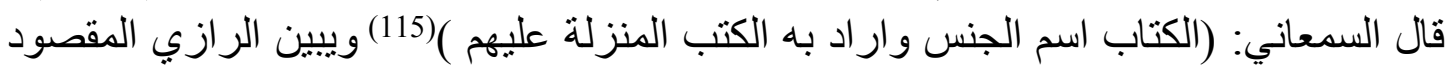
بالايتاء في هذه الآية إذ قال : (ويحتمل أن يكون المراد من هذا الايتاء الابتداء بالوحي والتهاء التنزيل

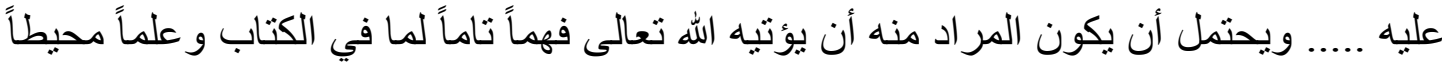

بحقائقه و أسر اره )(116).

7.

اقترن لفظ ( الكتاب ) معطوفاً عليه بلفظ ( الحكمة ) في تسعة مواضع في التنزيل القرآني

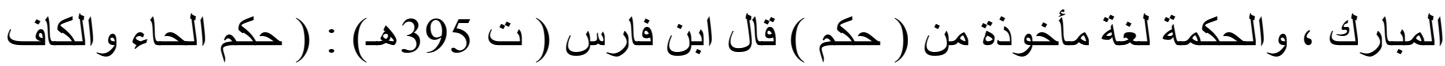

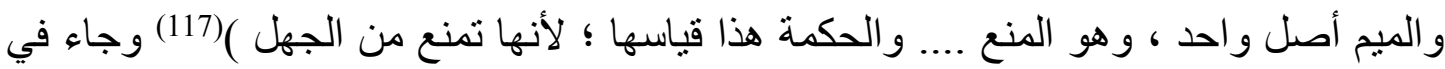

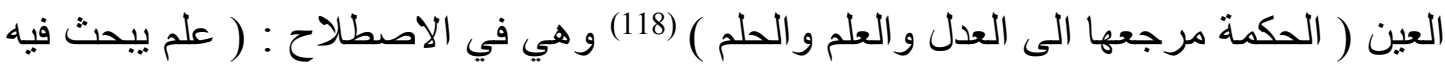

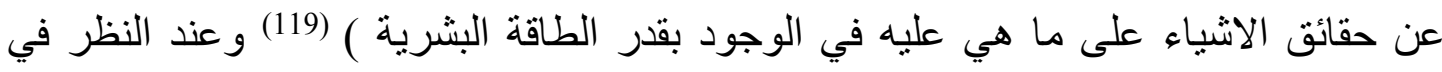
المو اضع التي اقترن فيها اللفظان (الكتاب و الحكمة ) نجد أن سنة مواضع منها قصد من الكتاب 
فيها القرآن الكريم (120) واختلف المفسرون في تفسير لفظ ( الحكمة ) في هذه المو اضع إذ ذهبوا

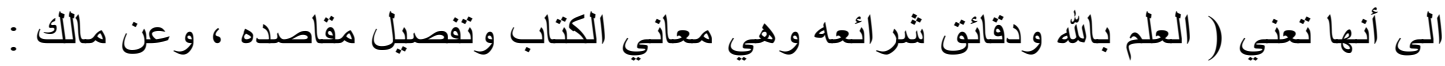

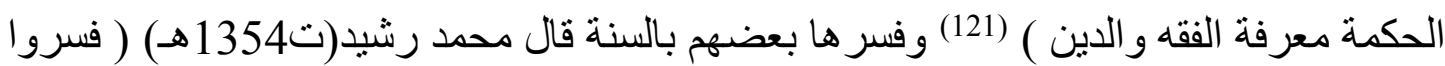

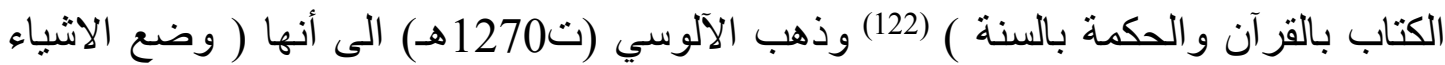

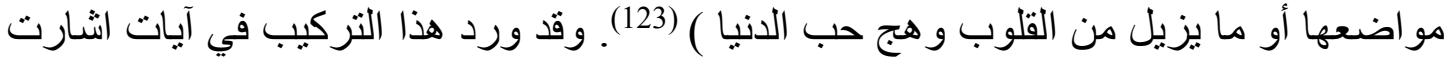

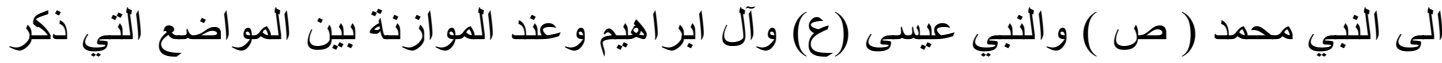

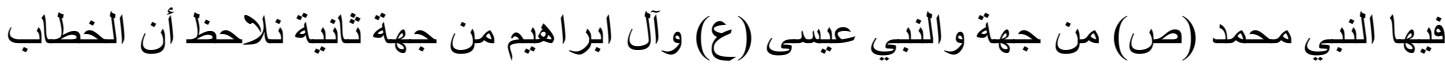

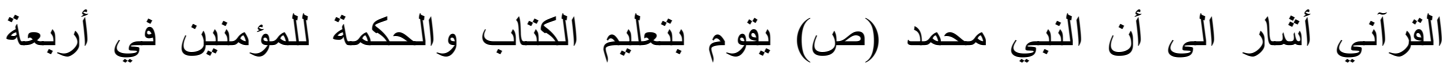

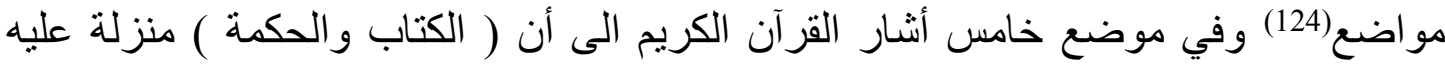

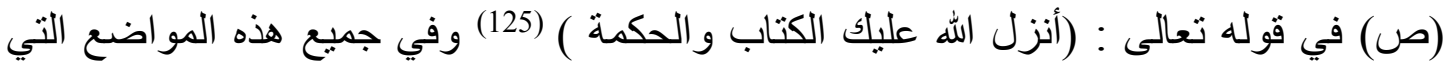

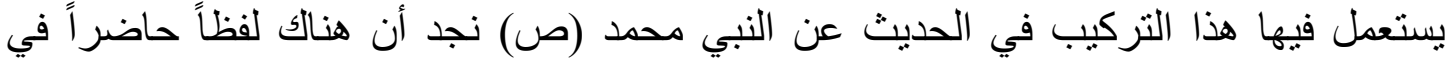

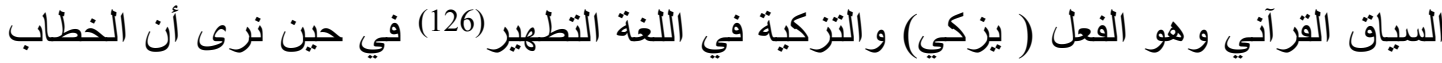

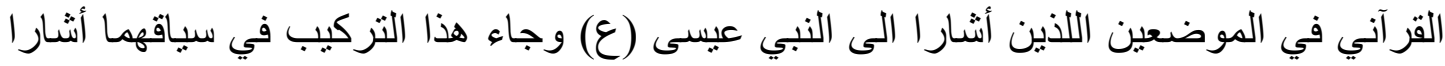

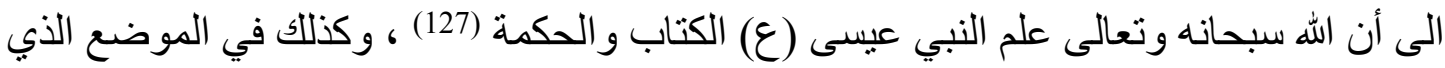

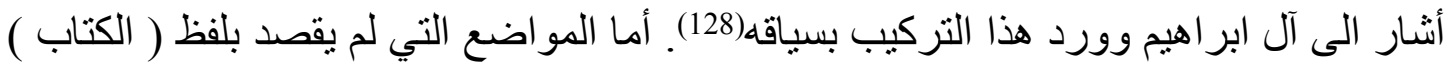

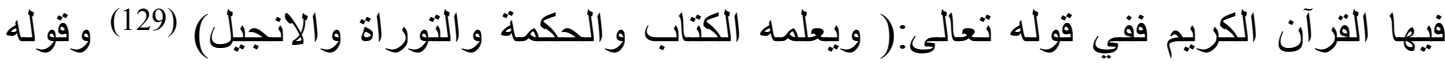

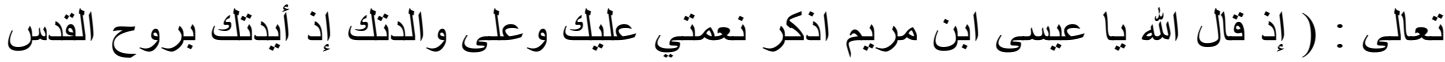

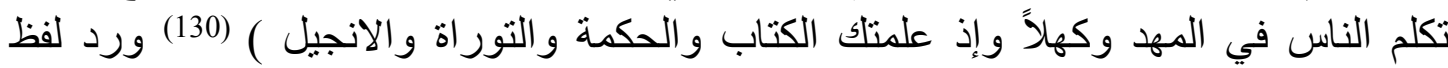

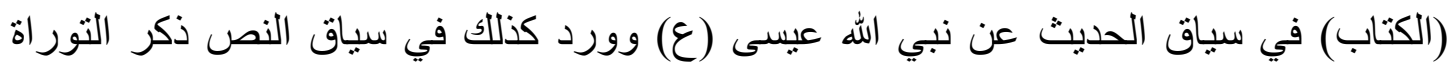

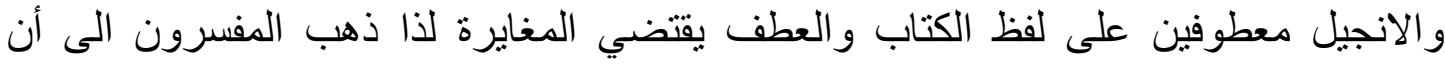

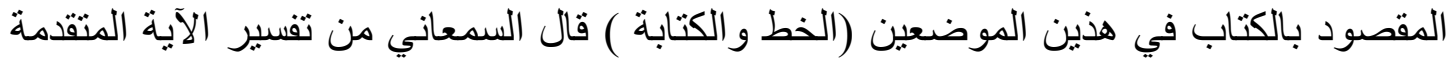

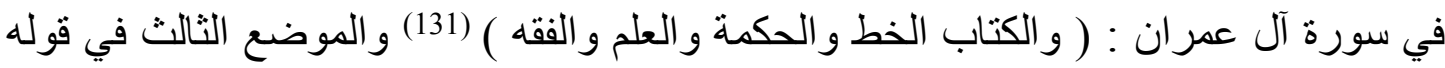

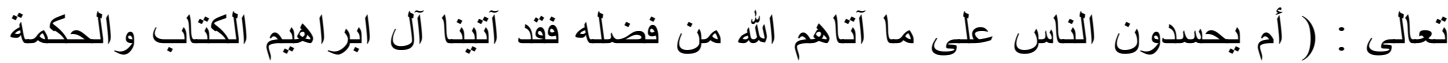

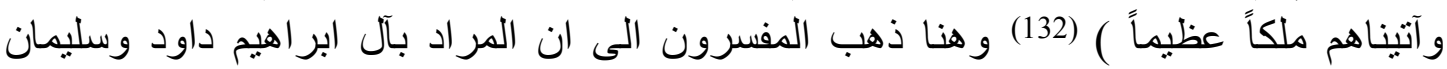

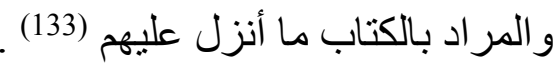

وبعد أن تناولنا ما كثر من التراكيب التي اقترن فيها لفظ الكتاب بغيره ، يمكن أن نثير الى في الكي

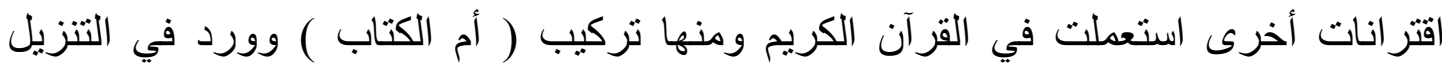

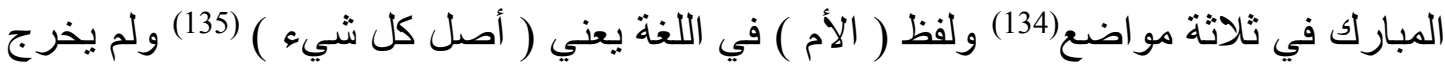

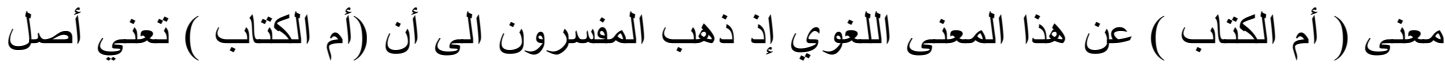

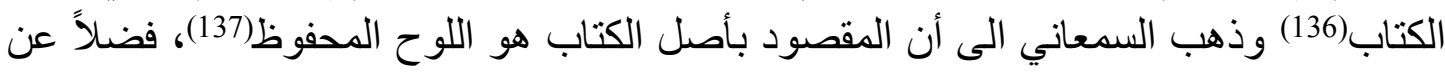
الاقترانات المتقدمة فقد وصف الكتاب بأوصاف منعددة منها ( كتاب مبين ) في خمسة الكسة الكناب 
مو اضع(138) ولفظ (مبين) من الالفاظ التي استعملت صفة لكثير من الألفاظ في القر آن الكريم إذ

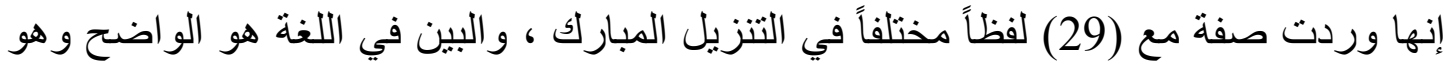

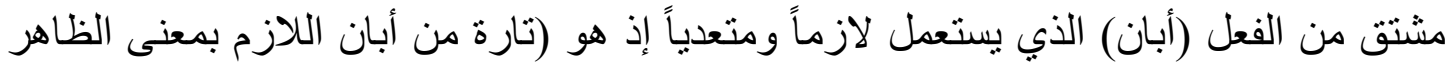

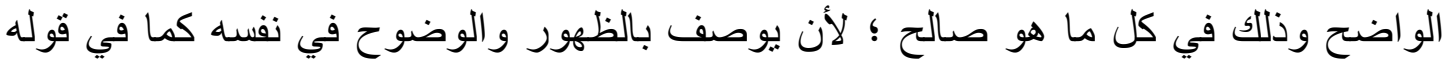

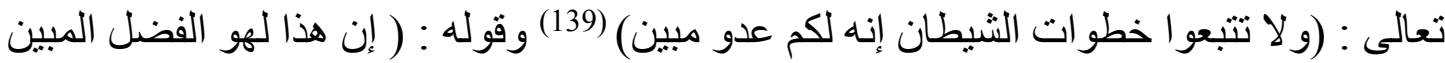

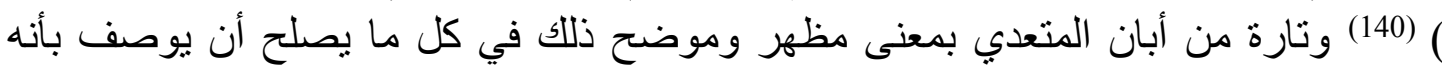

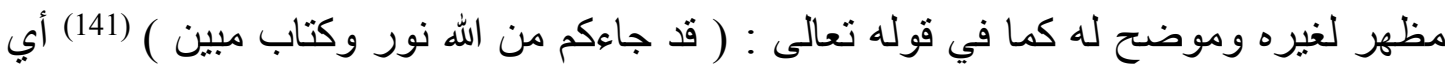

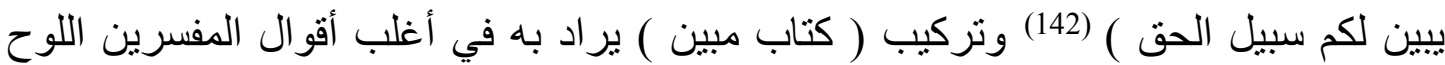
المحفوظ ففي قوله تعالى : (كل في كتاب مبين ) (143) قال الواحدي (ت مبين ) يريد اللوح المحفوظ ) (144) وفي جميع المو اضع التي اقترن فيها لفظ (كتاب) بلفظ (مبين) نجد في السياق القرآني الحديث عن السموات والارض وض والكون والخلق مما يدعم ر أي المفسرين في أن المقصود بكتاب مبين هو اللوح المحفوظ لثمولية اللوح المحفوظ بكل ما هو كائن الى يوم

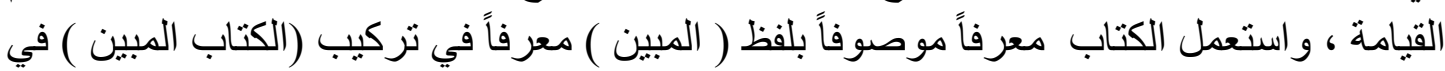
ثلاثة مو اضع (145) وقد ذهب أغلب المفسرين الى أن المر اد بالكتاب المبين هو القرآن آنساب الكريم(146)

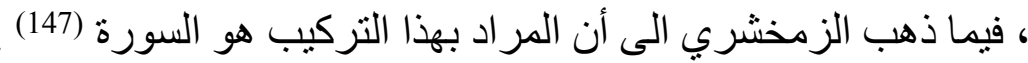

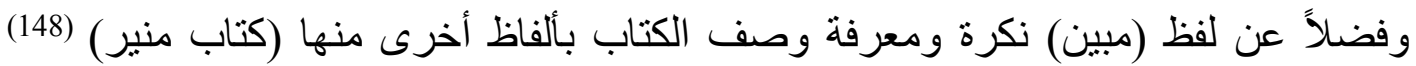

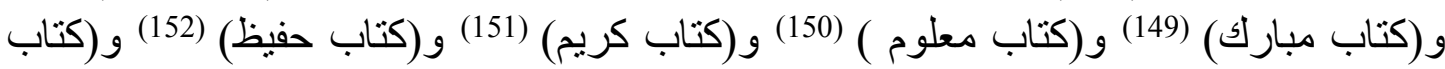

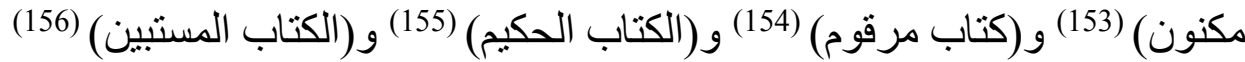

\section{دلالة لفظ الكتاب في الاستعمال القزآنى :}

بعد أن وقفنا على طائفة من الألفاظ التي اقترن بها لفظ الكتاب في القرآن الكريم وبيّنا أهم المعاني التي أفادها هذا اللفظ في النظم القرآني عند اقترانه مع هذه الالفاظ يلزمنا استقراء

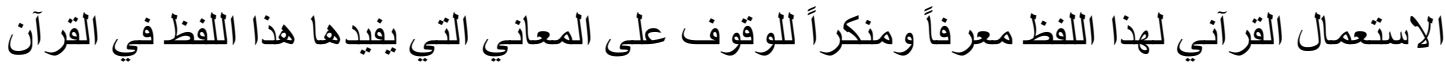

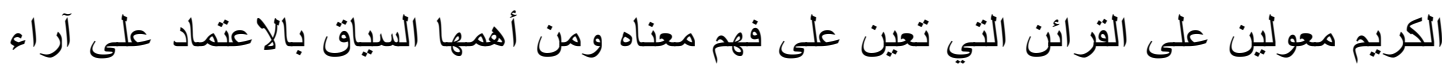
المفسرين ويمكن أن نجمل المعاني التي يفيدها هذا اللفظ على النئ النحو الآتي :

ورد لفظ (الكتاب) معرفاً ومنكر اً بمعنى القرآن الكريم في كثير من المواضع في التنزيل المبارك

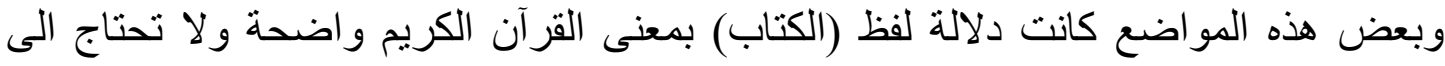

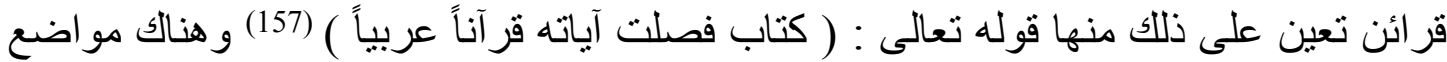

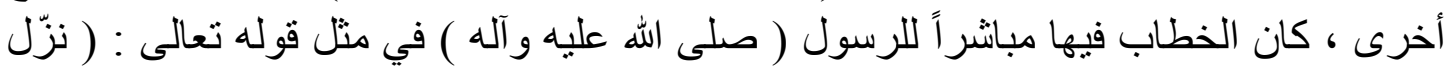


عليك الكتاب ) (158) وقوله تعالى : ( أنزل عليك الكتاب ) (159) وقوله تعالى : ( إنا أنزلنا اليك

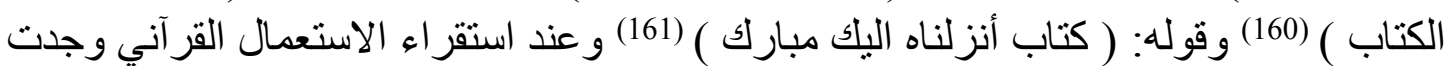

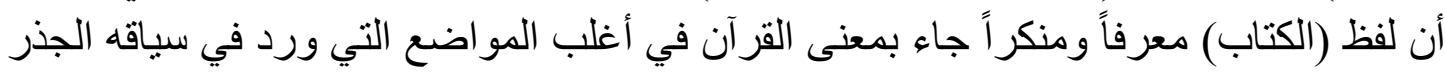

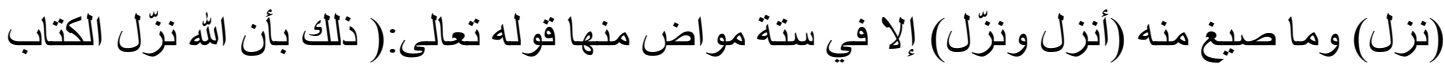
بالحق) (162) إذ ذهب الطبرسي (ت

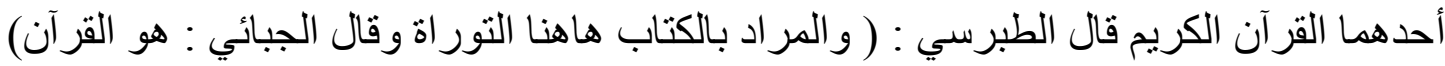

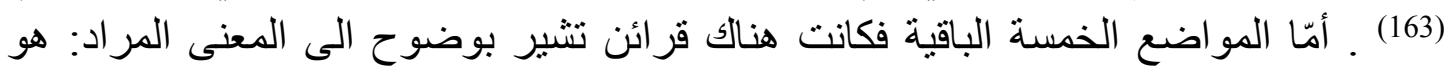

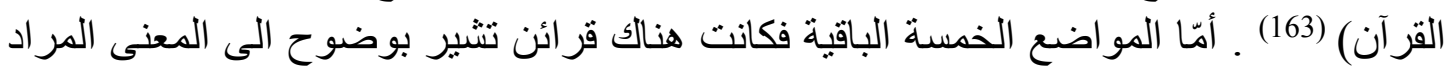
من لفظ (الكتاب) و هو غير القرآن الكريم(164) .

وكذلك يظهر الاستقر اء أن لفظ (الكتاب) دلّ على معنى القرآن الكريم عند وروده في سياق

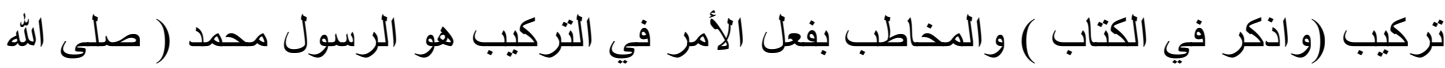

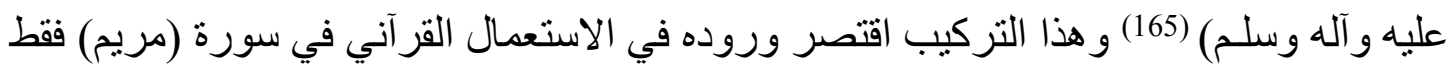
وورد فيها في خمسة مو اضع(166) ومن الآيات المباركة التي استعمل فيها لفظ (الكتاب) مرنين

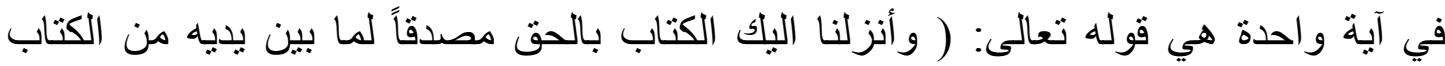

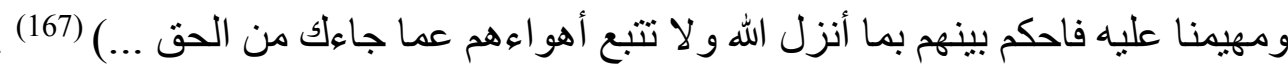

إذ ورد فيها لفظ الكتاب في المرة الاولى بمعنى (القرآن) بقرينة الخطاب للنبي محمد (ص) في مفتتح الآية وهو قوله: ( و أنزلنا اليك) فيما أُريد بلفظ (الكتاب) في المرة الثانية الكتب السماوية

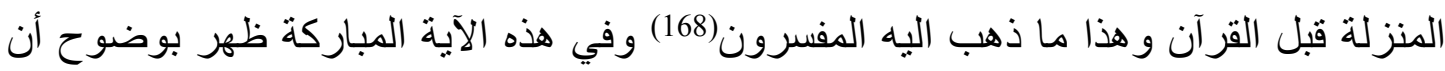

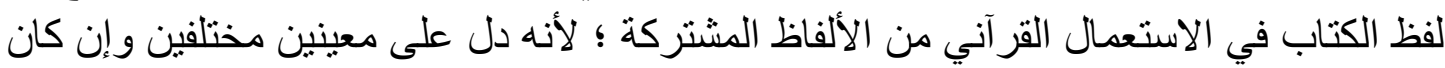

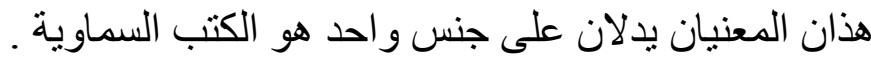

\section{التوراة والانجيل :}

استعمل لفظ ( الكتاب ) معرفاً للالالة على التوراة والانجيل وورد نكرة مضافاً في موضع و احد يدل على التور اة في قوله تعالى: ( ومن قبله كتاب موسى) (169) و اضافة لفظ (الكتاب) نكرة

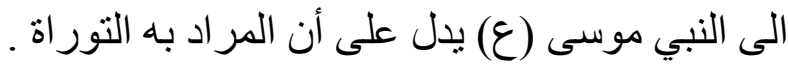

و عند استقراء الاستعمال القرآني نجد أن القرآن الكريم أراد بلفظ (الكتاب) في أغلب الأحيان

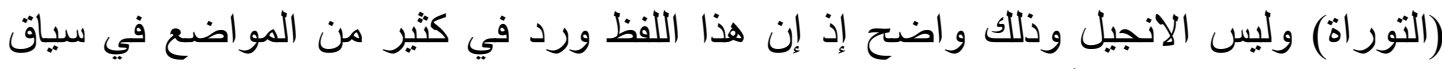

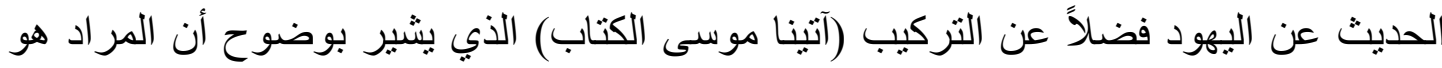

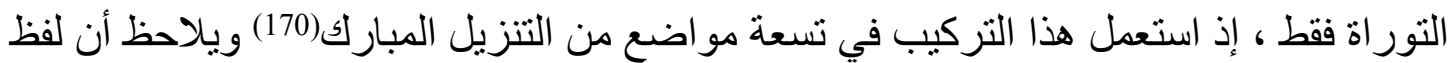
(الكتاب) إذ كان بمعنى التور اة يكون مفترناً بالفعل (آتى) . 
أما إذا أريد بلفظ (الكتاب) التور اة والانجيل فإن هناك قر ائن تعين على ذلك منها السياق كما

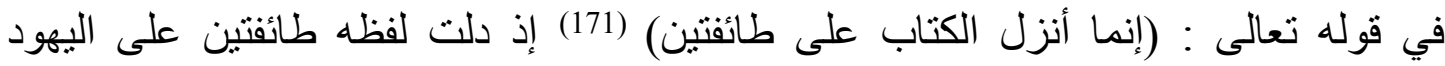
و النصارى وقوله تعالى:(وقالت اليهود ليست النصارى على شيء وقالت وقالت النصارى ليست اليهود على شيء وهم يتلون الكتاب) (172) .

وفي موضع واحد فقط أُريد بلفظ (الكتاب) معنى الانجيل وذلك في قوله تعالى: ( قال إني عبد

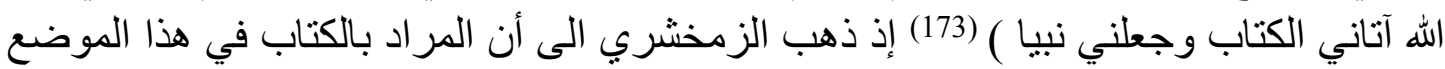
(الانجيل) (174) ؛ لأن اللفظورد في سياق الحديث عن قصة النبي عيسى ( عليه السلام ) .

\section{3.اللوح المحفوظ}

ورد تركيب اللوح المحفوظ في الاستعمال القرآي مرة واحدة وذلك في قوله تعالى: ( بل هو

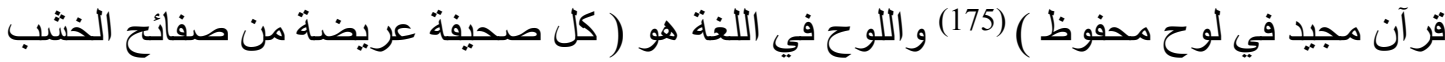
... و اللوح الذي يكتب فيه ) (176) ، وقد ذهب المفسرون الى تفسير لفظ (الكتاب) في كثير من هن الفئ

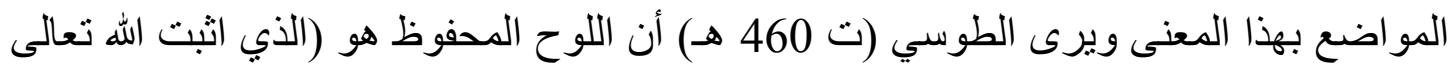

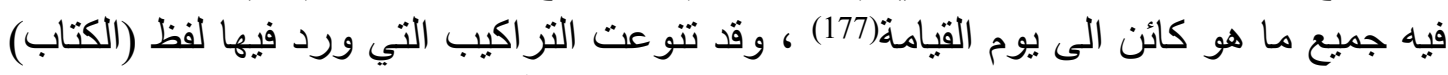

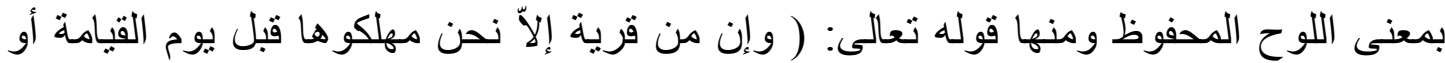

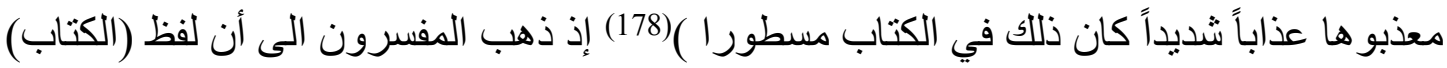
في الآية الكريمة بمعنى (اللوح المحفوظ) (179) وذللك اعتماداً على معنى لفظ (مسطور ) فئل ؛ لأنه

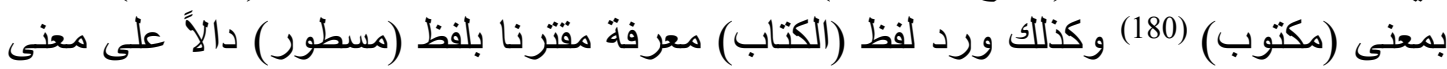

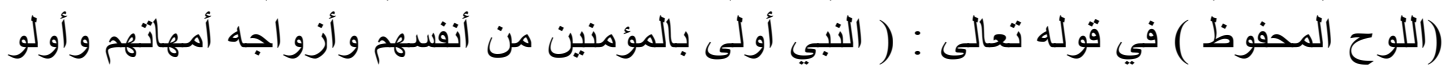

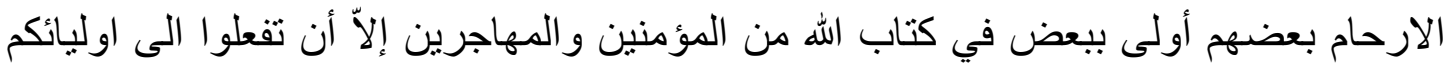

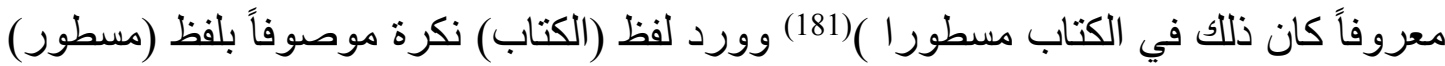

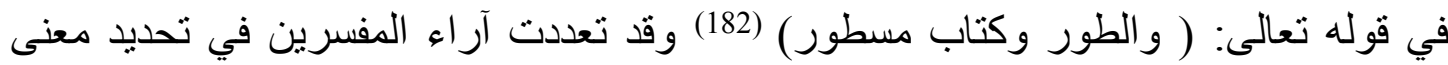
الكتاب في هذه الآية وكان معنى اللوح المحفوظ من بين هذه المعاني التي ذهب الئ ولئ المفسرون(183)

وقد وجدت أن لفظ (الكتاب) نكرة موصوفاً بلفظ (مبين) ورد في الاستعمال القر آني في خمسة

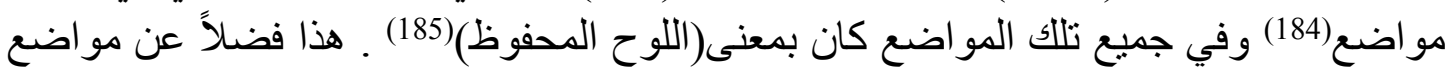
أخرى(186) ورد فيها لفظ (الكتاب) بمعنى (اللوح المحفوظ) دون وجود قرينة لفظية تدل على ذلك فون

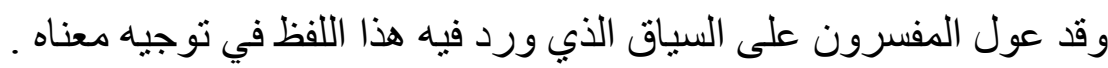
4. جنس الكتاب : 
استعمل لفظ (الكتاب) في القرآن الكريم بمعنى عام هو جنس الكتاب ، إذ استعمل اللفظ ولم يُرد

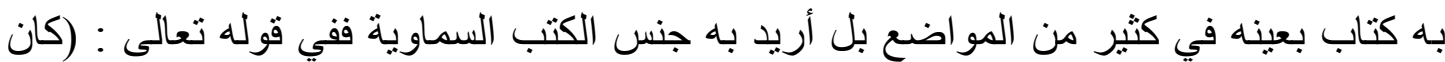
الناس أمة و احدة فبعث الله النبيين مبشرين ومنذرين و أنزل معهم الكتاب بالحق ليحكم بين الناس

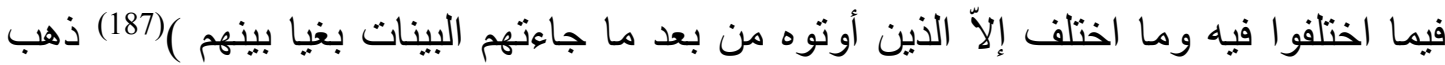
الزمخشري الى أن المر اد بالكتاب في الآية هو جنس الكتاب(188) وقال الطبرسي:( وقيل وفيل المر اد اد

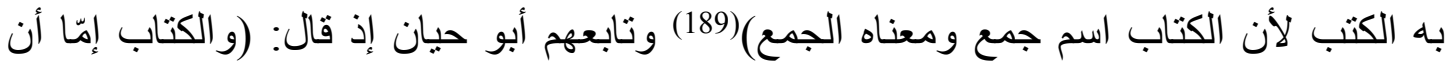
تكون (ال) فيه للجنس و إمّا أن تكون للعهد)(190). ومعلوم أن كتب الانبياء السماوية متعددة ولما لم الم المان

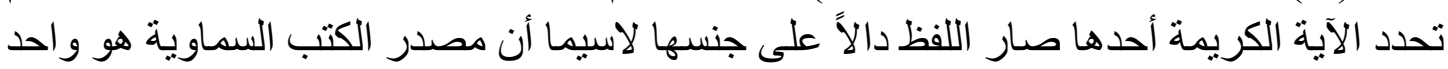

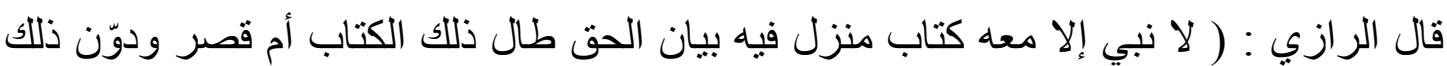

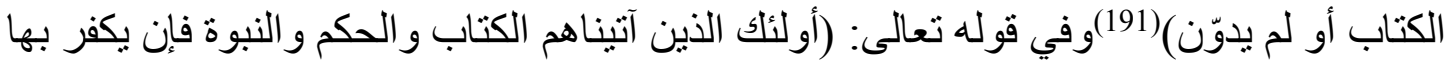

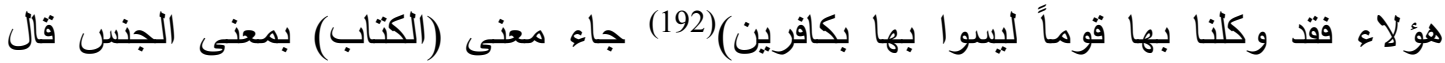

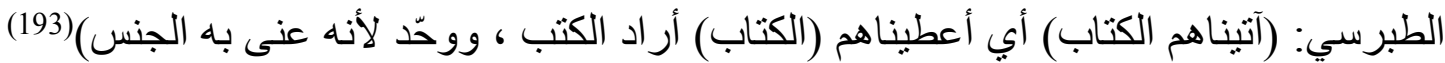

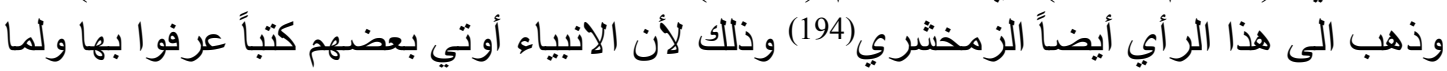

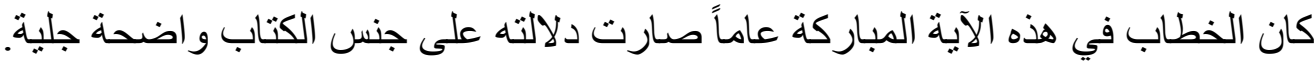
وفي قوله تعالى: (فلذللك فادعُ واستقم ولا تتبع أهواءاهم وقل آمنت بما أنزل الله من كتاب

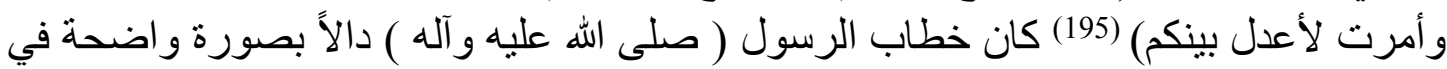

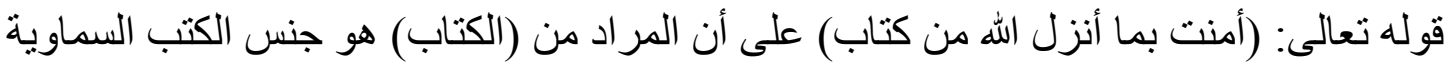

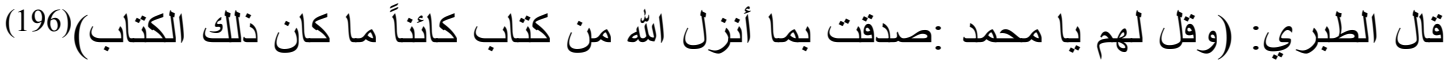
وكذلك يمكن تلمس دلالة هذا المعنى للفظ (الكتاب) في طائفة أخرى من الآيات المباركة بالاستعانة بقرينة السياق وقد دل بعض المفسرين عليها في مو اضعها(197)

\section{5 الصحيفة: 5}

و هو أصل معنى لفظ (الكتاب) يقول الر اغب الاصفهاني(ت425هـ) : (والكتاب في الأصل اسم للصحيفة مع المكتوب فيه)(198) وقد استعمل بهذا المعنى في بعض المول اضع الرع من القرآن

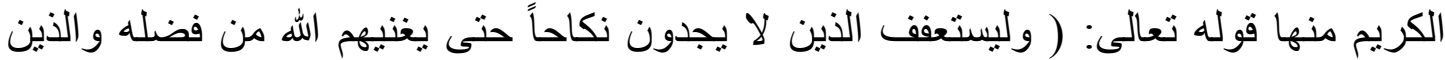

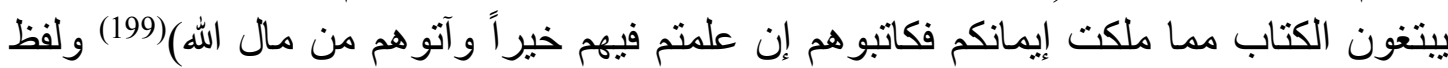

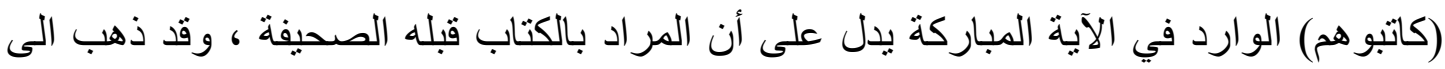

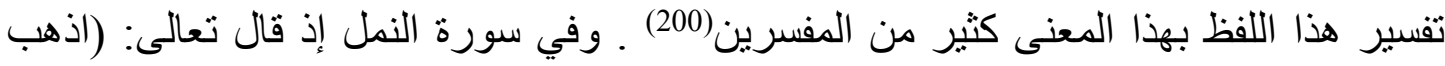
بكتابي هذا فالِِها اليهح ثم تول عنهم فانظر ماذا يرجعون* قالت يا أيها الملأ إني ألقي إليّ كتاب

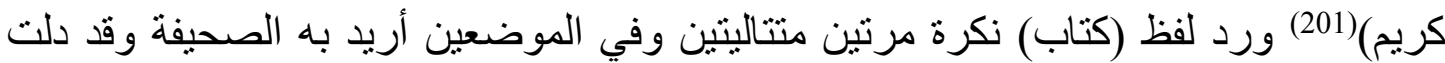
الألفاظ الواردة في سياق الآيتين على أن المراد من هذا اللفظ الصحيفة المكتوب فيها بدلالة لفظ 
(فالقه) وفي الآية اللاحقة و هي قوله نعالى: (إنه من سليمان و إنه بسم الله الرحمن الرحيم)(202)

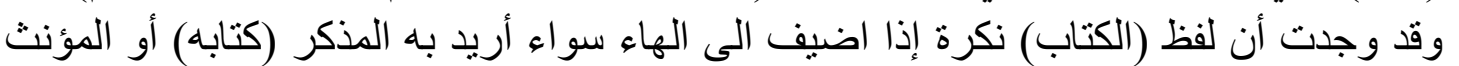

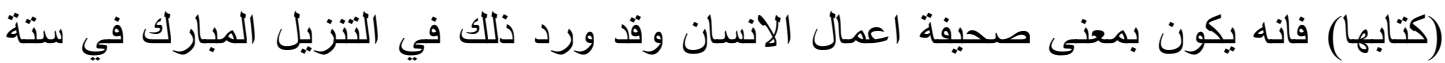

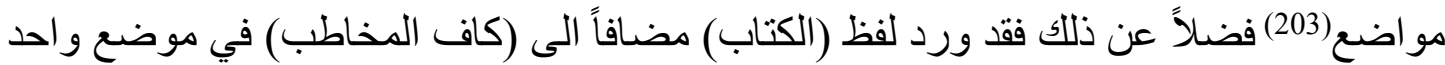
من التنزيل المبارك و أريد به صحيفة الاعمال(204) .

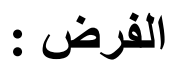

.6

أريد بلفظ (الكتاب) في موضعين فقط من التنزيل المبارك معنى (الفرض) وهو في اللغة:

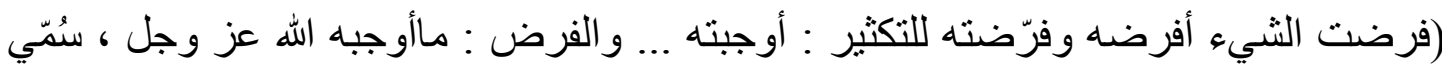

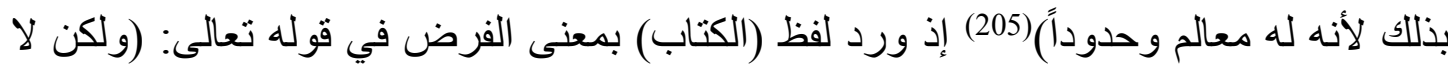

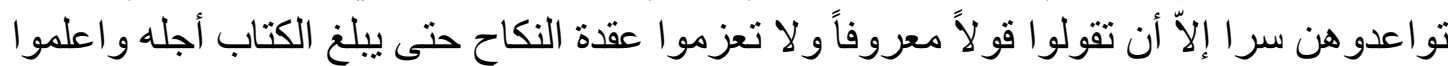

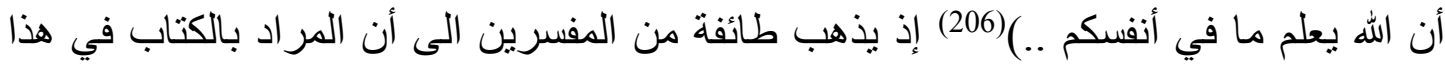

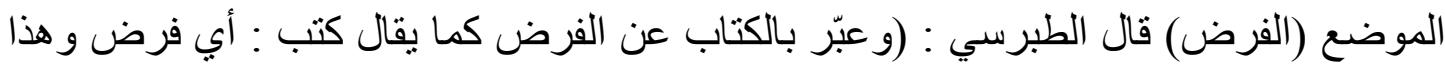

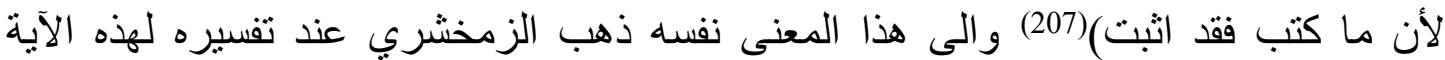

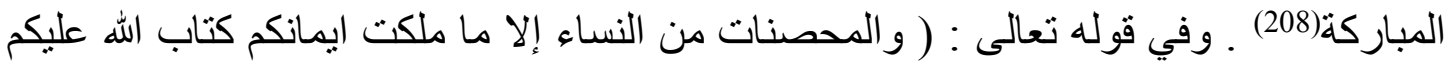

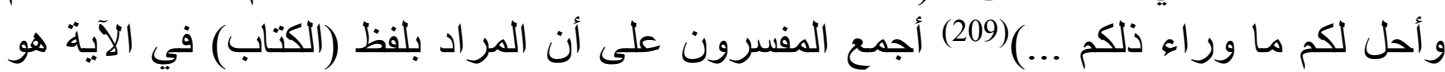
(الفرض) مل مان

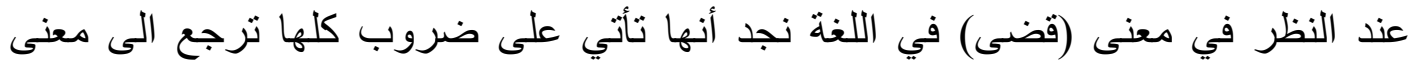

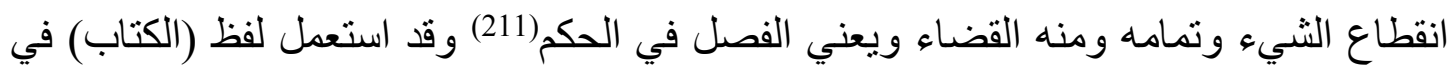

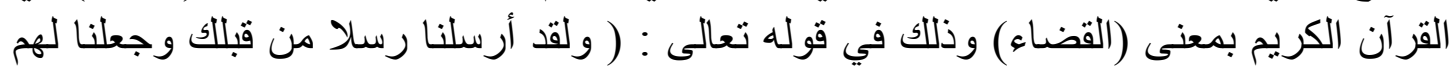

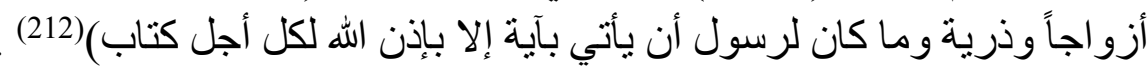

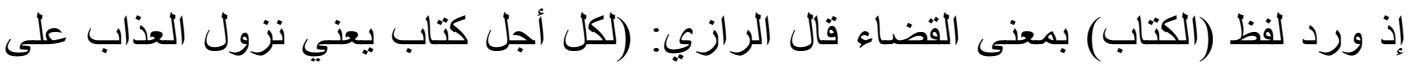

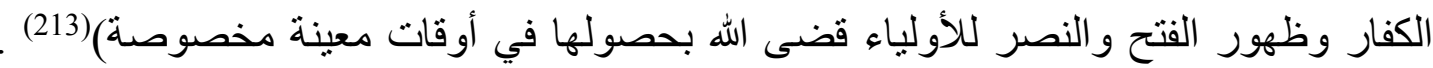

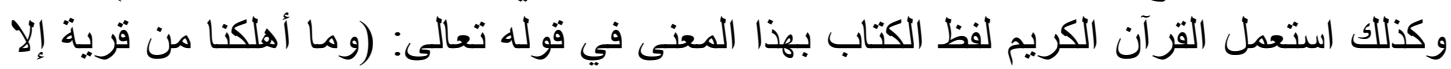

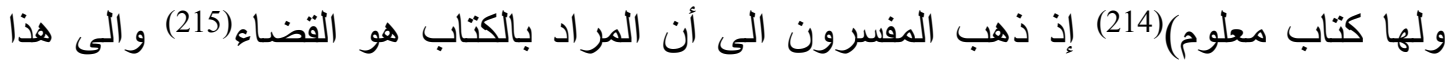
المعنى ذهب الفر اهي(ت1349 هـ) في كتابه مفردات القرآن عند تعرضها لتفسير معنى (الكتاب) 
في الآية الكريمة ، وقد استدل محقق الكتاب على صحة ما ذهب اليه الفراهي بطائفة من الثو اهد الثعرية(216)

\section{السورة : 20 (السورة}

.8

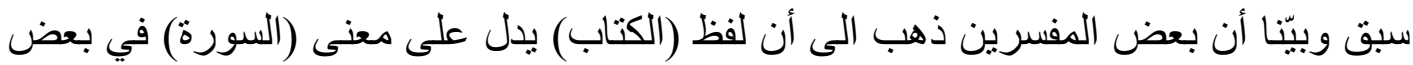

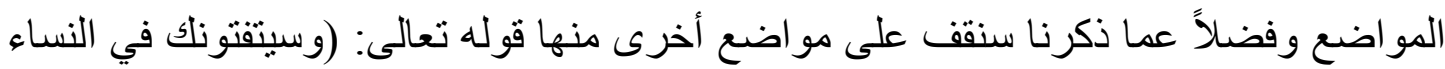

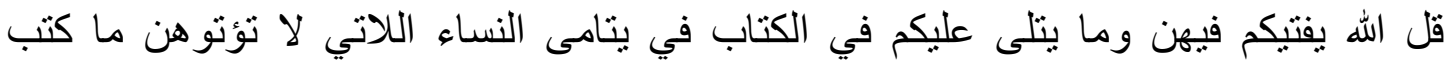

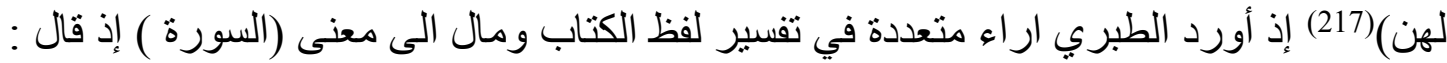

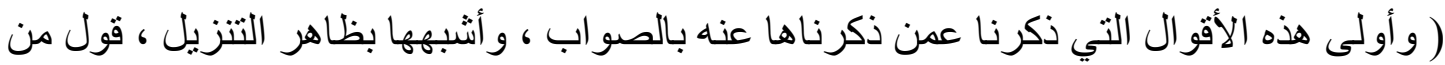

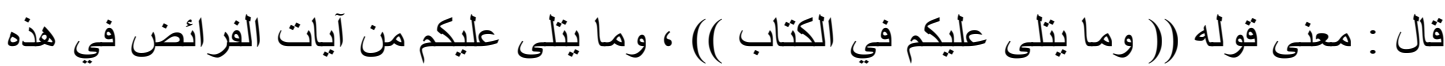

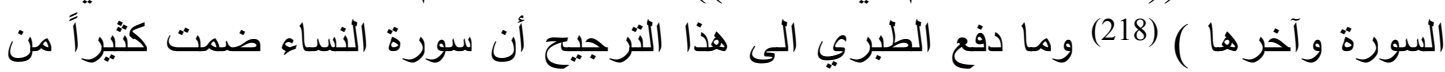
الأحكام لذا عدها كتاباً قائماً بنفسه وفسر لفظ الكا (الكتاب) في هذا الموضع بمعنى (السورة) . وكذلك فسر الزمخشري لفظ (الكتاب) بالسورة في قوله تعالى: (كتاب أنزل اليك فلا يكن في

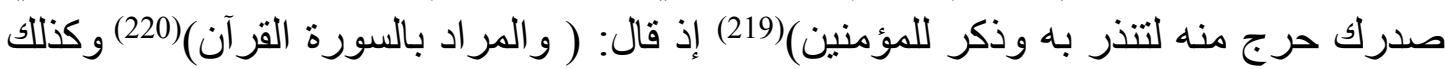

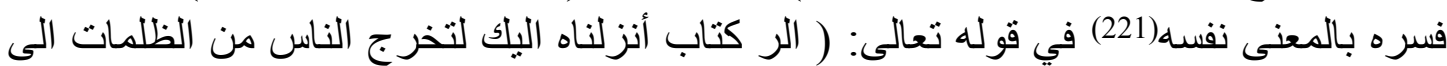

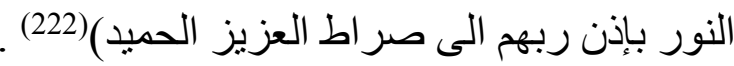

هذا فضلاً عن أن الزمخشري انفرد في تفسير لفظ (الكتاب) بمعنى الوحي وذللك في موضعين

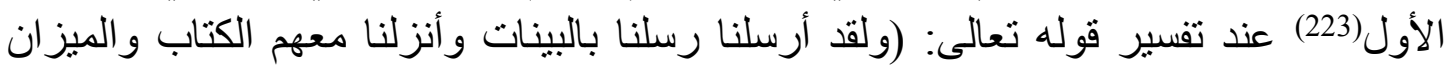
ليقوم الناس بالقسط)(224) والآخر (225) عند تفسير قوله (225) تعالى: ( ومن الناس من يجادل في في الله

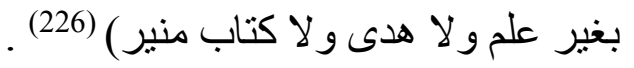

و هذه هي المعاني التي استعمل فيها لفظ (الكتاب) نكرة ومعرفة في الاستعمال القر آني .

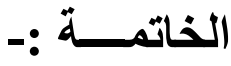

لفظ (الكتاب) من الفاظ المشترك اللفظي ؛ لأنه يدل على معانٍ متعددة أوردتها المعجمات

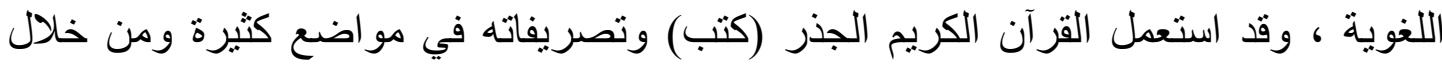

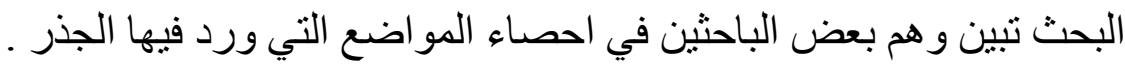


وقد وقف البحث عند استعمال لفظ (الكتاب) في القرآن الكريم فبين المعاني التي أفادها عند

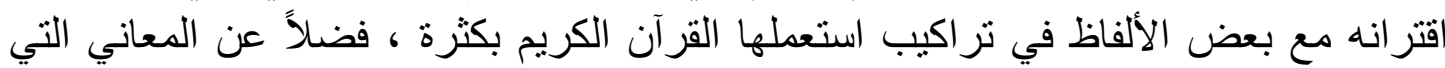
أفادها بشكل عام سواء استعمل نكرة أو معرفة ويمكن أن نلخص أهم النتائج التي توصل الئه اليها

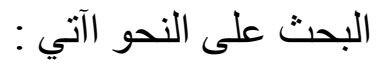

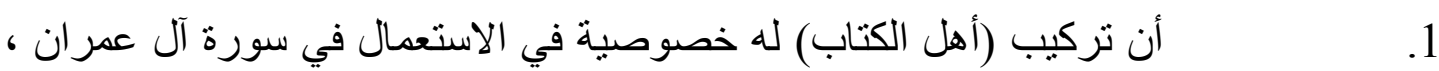

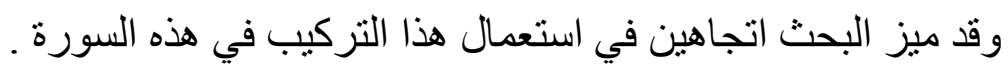

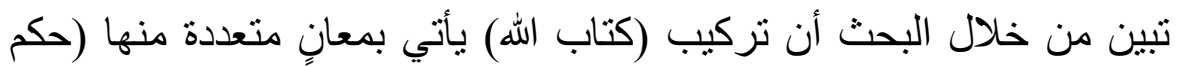

الله) وفي جميع المواضع التي أريد بها هذا المعنى ورد التركيب مسبوقاً بحرف الجر (في) لئي

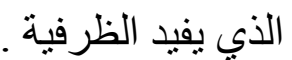

تبين من خلال البحث أن تركيب (أهل الكتاب) اطلاق عام يراد به اليهود

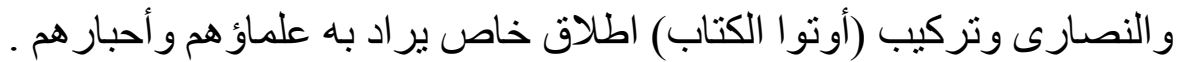

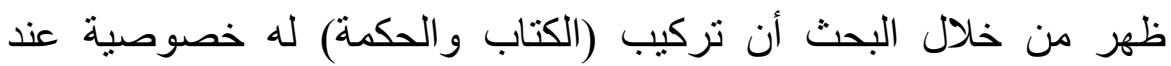

استعماله في الحديث عن النبي محمد (صلى الله عليه و آله) وفي جميع تللك المو اضع ورد في في في

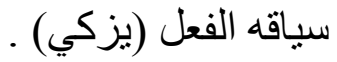

استقصى البحث المعاني التي أفادها لفظ (الكتاب) عند استعماله غير مقترن

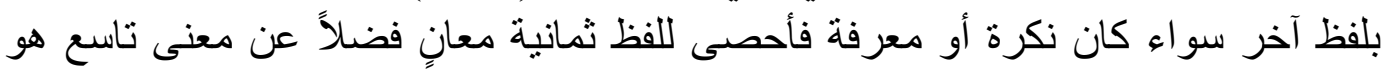

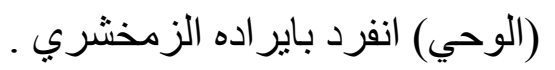

عند النظر في المعاني المتنوعة للفظ ( الكتاب ) في القر آن الكريم يمكن الجزم

بأن اللفظة من ألفاظ المشترك اللفظي في القرآن الكريم .

$$
\text { *المصادر والمراجع :- }
$$

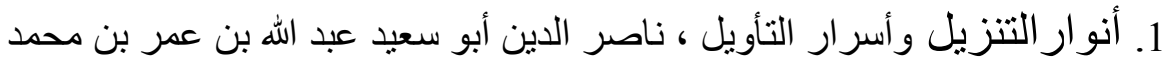

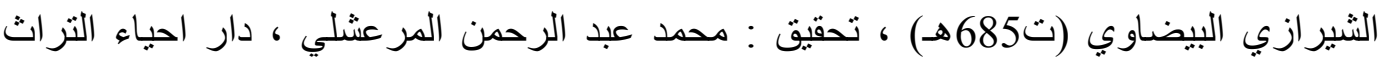

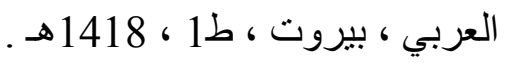

2. أضو اء البيان في ايضاح القرآن بالقر آن ، محمد الأمين بن محمد المختار بن عبد المبار

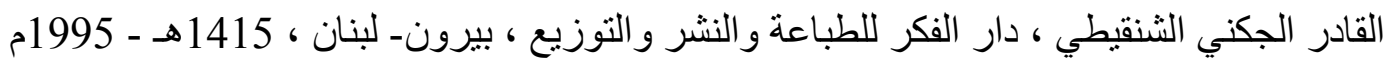


3. البحر المحيط في التفسير ، أبو حيان محمد بن يوسف بن علي بن يوسف بن

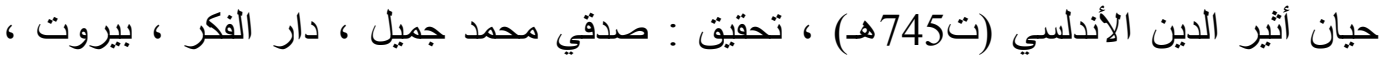
1420

4. تاج العروس من جواهر القاموس ، محمد بن محمد بن عبد الرزاق الحسيني

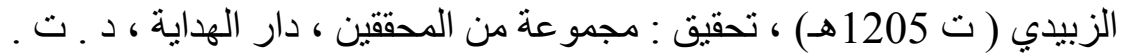

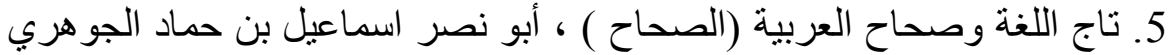

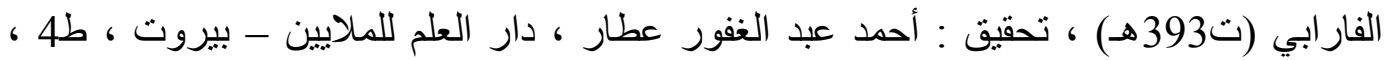

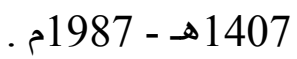

6. التبيان في تفسير القرآن ، شيخ الطائفة أبي جعفر محمد بن الحسن الطوسي

(ت460هـ) ، تحقيق : احمد حبيب قصير العاملي .

7. تحرير المعنى السديد وتنوير العقل الجديد من تفسير الكتاب المجيد ، محمد

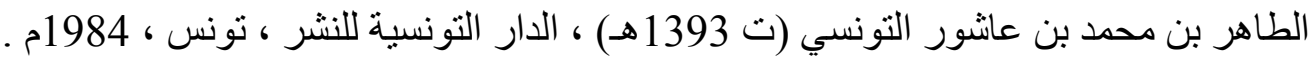

8. التصاريف لتفسير القرآن مما اشتبهت اسمائه وتصريف معانيه ، يحيى بن سلام

بن أبي ثعلبة الافريقي القيرواني (ت200هـ) ، تحقيق : هند شلبي ، الثركة التونسية للتوزيع ،

9. تفسير القرآن ، أبو المظفر منصور بن محمد بن عبد الجبار بن أحمد المروزي

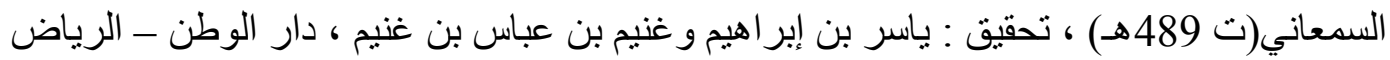

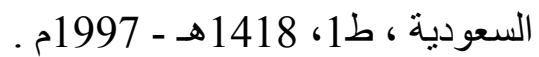

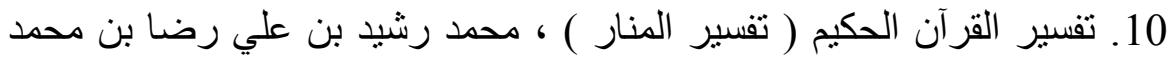

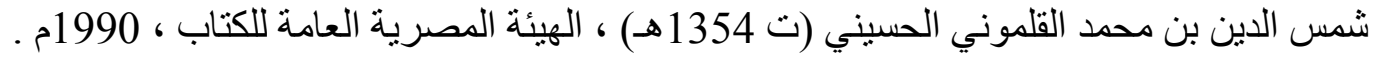
11. تفسير القرآن العظيم ، أبو الفداء اسماعيل بن عمر بن كثير القرشي داري

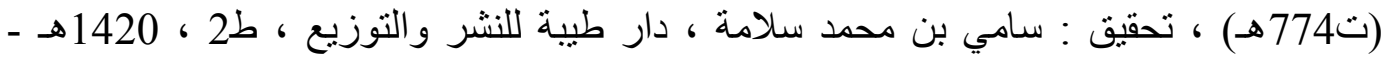

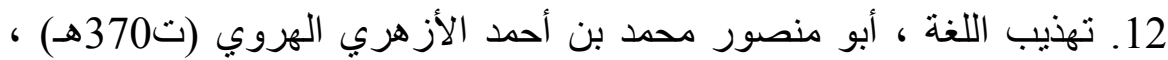

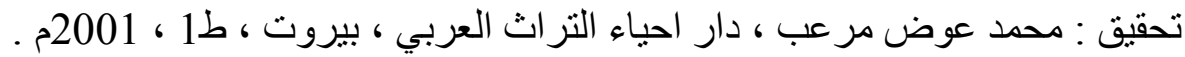

13. جامع البيان في تأويل القرآن ، أبو جعفر محمد بن جرير بن بزيد الطبري

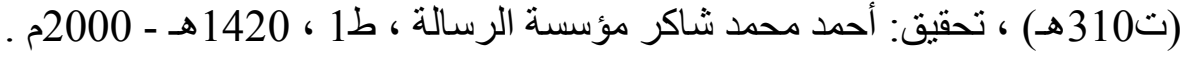


14. جامع الدروس العربية ، الثيخ مصطفى الغلاييني ، مر اجعة سالم شمس الدين

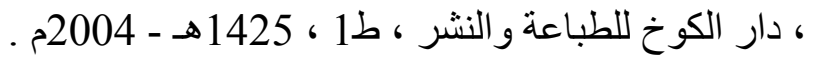

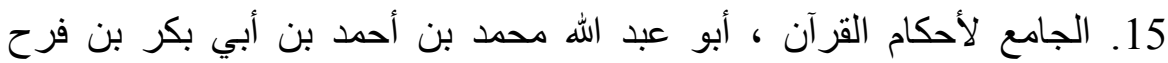

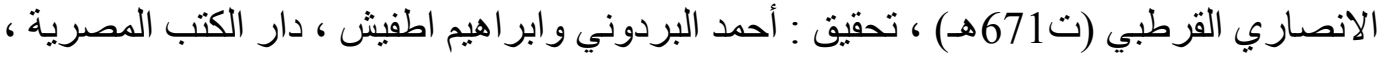
القاهرة ، ط2 ، 1384 هـ - 1964 م .

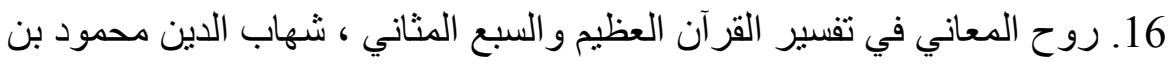

عبد الله الحسيني الالوسي (ت1270هـ) ، تحقيق : علي عبد الباري عطية ، دار الكتب العلمية ـ ـ

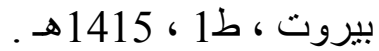

17. علم الدلالة ، د. أحمد مختار عمر ، مكتبة دار العروبة للنشر و التوزيع ، ط1 ،

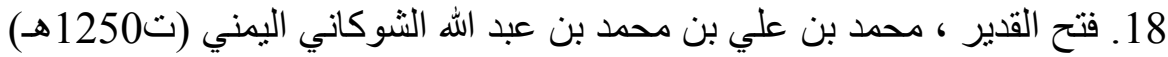

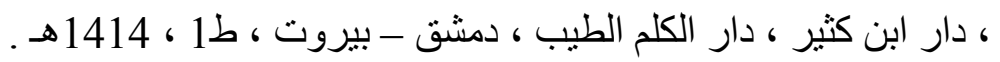

19. كتاب التعريفات ، علي بن محمد بن علي الزين الثريف الجرجاني

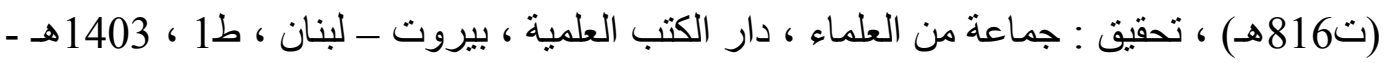

20. كتاب العين ، أبو عبد الرحمن الخليل بن أحمد بن عمرو بن تميم الفراهيدي

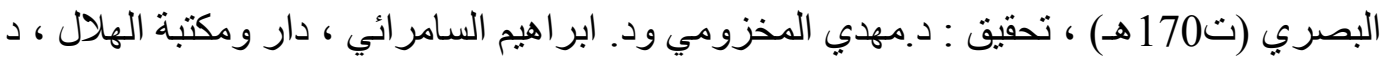

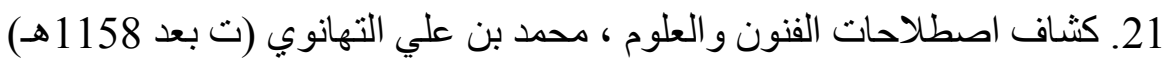

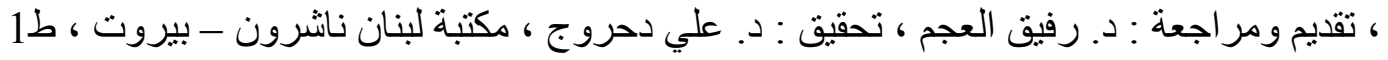

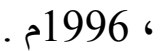

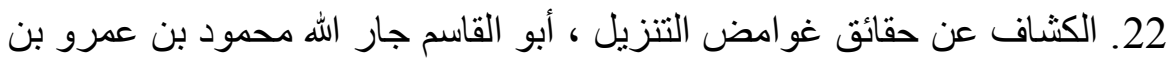

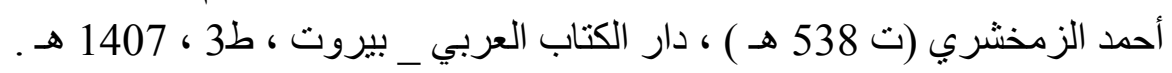

23. الكثف و البيان عن تفسير القرآن ، أبو اسحاق أحمد بن محمد بن ابراهخيم

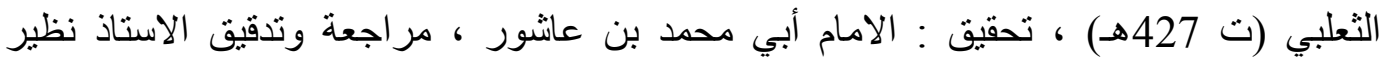
الساعدي ، دار احياء التراث العربي ، بيروت _ لبنان ، ط1 ، 1422 هـ ــ ــ 2002 م .

24. الكليات معجم في المصطلحات والفروق اللغوية ، أبو البقاء ايوب بن موسى هـ

الحسيني الكفوي (ت 1094 هـ) ، تحقيق : عدنان درويش ومحمد المصري ، مؤسسة الرسالة ، بيروت ، د.ت . 


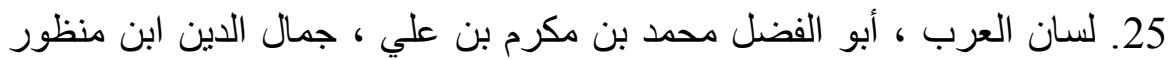

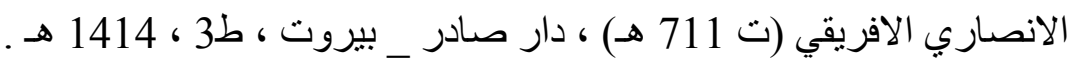

26. مجمع البيان في تفسير القرآن ، أبو علي الفضل الحسن الطبرسي (ت 561 هـ )

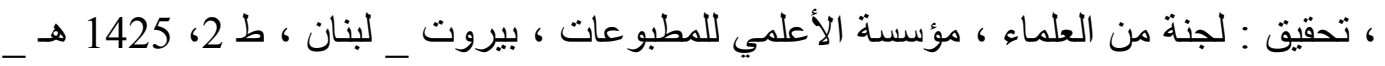

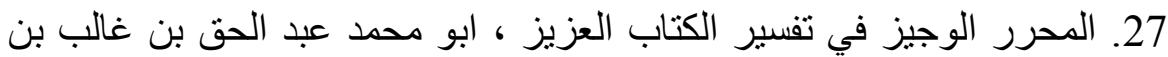

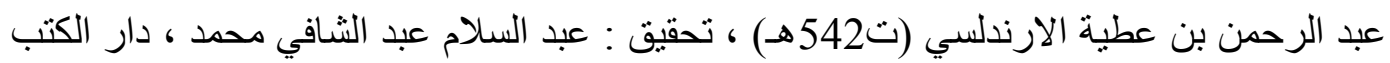

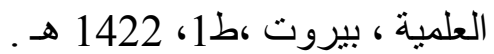

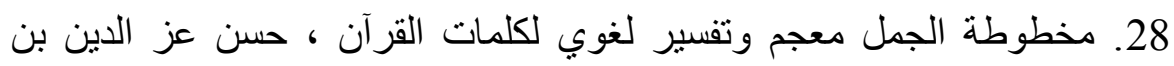

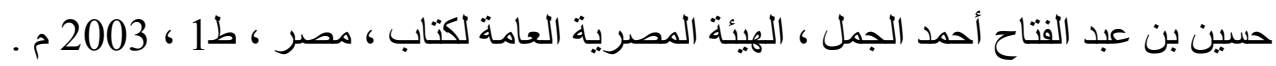

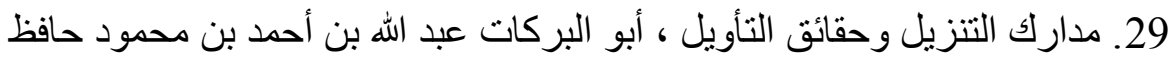

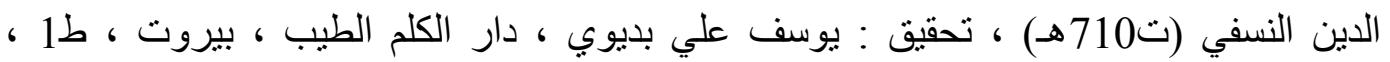

1419هـ - 1998م.

30. معالم التنزيل في تفسير القرآن ، أبو محمد الحسين بن مسعود بن محمد بن ،

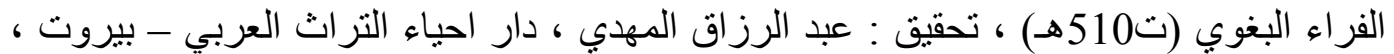

31. معاني القرآن واعرابه ، أبو اسحاق ابراهيم بن السري بن سهل الزجاج

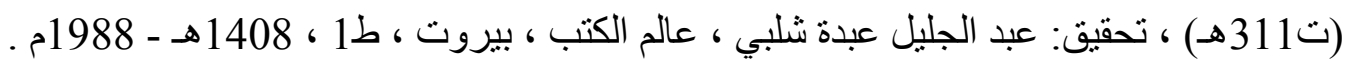

32. معجم مقاييس اللغة ، أبو الحسن أحمد بن فارس بن زكرياء الرازي

(ت395هـ) ، تحقيق : عبد السلام محمد هارون ، دار الفكر ، 1399هـ - 132 بـ 1979م .

33. مفاتيح الغيب ، أبو عبد الله محمد بن عمر بن الحسن بن الحسين الرازي

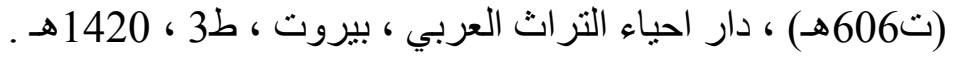

34. مفردات الفاظ القرآن ، الراغب الاصفهاني (ت425هـ) ، تحقيق : صفوان

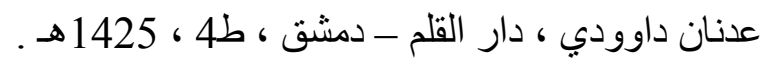

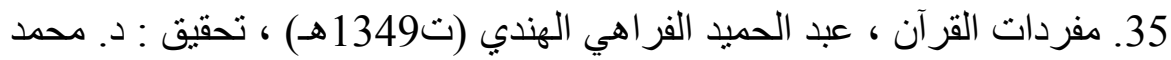

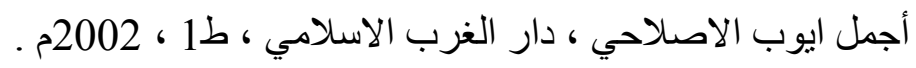


37. النكت والعيون ، أبو الحسن علي بن محمد بن محمد بن حبيب البصري

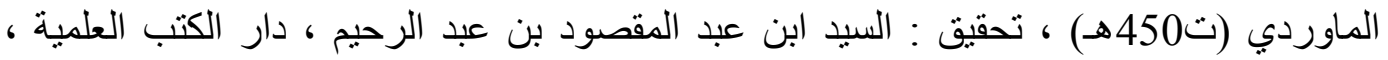
بيروت ـ لبنان ، د ـ ت . .

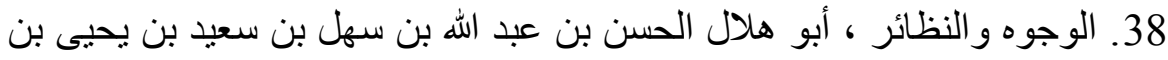

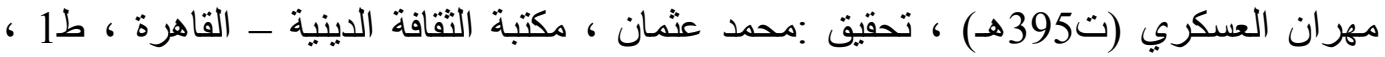

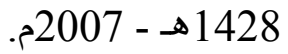

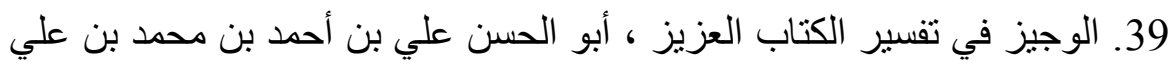

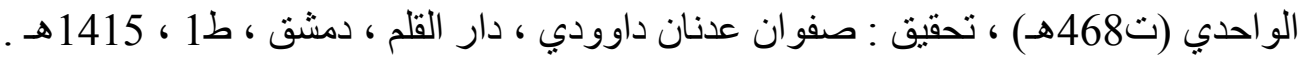

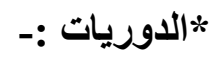

* الاسلام و الكتابة العربية ، د. حسام سعيد النعيمي ، مجلة الضاد ، الجزء الثالث ، 